Gradient Auxiliary Selection and Impersonal Passivization in German: An Experimental Investigation

FRANK KELLER AND ANTONELLA SORACE

University of Edinburgh 


\section{Gradient Auxiliary Selection and Impersonal Passivization in German: An Experimental Investigation ${ }^{1}$}

\section{Abstract}

The main purpose of this paper is to provide experimental evidence that two syntactic reflexes of split intransitivity in German - the selection of perfective auxiliaries and the impersonal passive construction are sensitive to an aspectual/thematic hierarchy of verb classes. We show that there is a split between 'core' verbs that elicit categorical intuitions from native speakers, and 'intermediate' verbs that exhibit gradience. Furthermore, crossdialectal differences between northern and southern German with respect to auxiliary selection tend to occur only with intermediate verbs. We argue that these findings lend support to the view that the unaccusative/unergative distinction is considerably more unstable than often assumed, and suggest that projectionist theories of the lexicon-syntax interface such as those directly derived from the Unaccusative Hypothesis may not be able to account for the systematic variation exhibited by the data. 


\section{INTRODUCTION}

\subsection{Split intransitivity: An Overview}

The Unaccusative Hypothesis, originally formulated within the Relational Grammar framework (Perlmutter 1978) and later the Government-Binding model (Burzio 1986), assumes that, across languages, intransitive verbs divide into two sub-classes, unaccusatives and unergatives, which have distinct syntactic and semantic properties. Syntactically, the subject of unaccusative verbs behaves like the direct object of transitive verbs, whereas the subject of unergative verbs behaves like the subject of transitive verbs. This configurational distinction is manifested in a number of syntactic properties exhibited by unaccusative verbs, which are also shared by a range of constructions involving operations on an internal argument, such as passives (Burzio 1986), the cliticization of partitive $n e$ in Italian (Belletti \& Rizzi 1981), the resultative construction in English (Levin \& Rappaport Hovav 1995), and the possessor dative in Hebrew (Borer 1994, 1996). The choice of the perfective auxiliary is also thought to involve a privileged syntactic relation between the subject and the object position and therefore to correlate with other syntactic properties of unaccusativity/unergativity, although, as pointed out by Grimshaw (1990; see also Alexiadou, Anagnostopoulou \& Everaert, in press), the structural distinction underlying the choice of auxiliaries is less transparent than for other diagnostics. ${ }^{2}$ Impersonal passivization is due to the absorption of the subject theta-role and thus requires the presence of an external argument (Grewendorf 1989, Hoekstra \& Mulder 1990); it is therefore regarded as a test for unergativity, since the single argument of unaccusative verbs is, by definition, internal.

Recent changes in syntactic theory have substantially changed the interpretation of the structural bases of unaccusativity. In particular, the VP-internal hypothesis (Koopman \& Sportiche 1991, among others) has led to the obliteration of the distinction between internal and external arguments: as the single arguments of unaccusative and unergative verbs are both generated within the VP domain, the structural representation of the distinction is given at the level of different functional (or semi-functional) heads to which each argument moves. These theoretical refinements appear to question the validity of those diagnostics, such as ne cliticization in Italian or impersonal passivization, which previously depended on the characterization of arguments as internal or external: indeed, it has been shown that these constructions can allow both unaccusative and unergative verbs (although not to the same extent), depending on semantic factors such as the mutual predictability between a verb and its argument (Levin \& Rappaport Hovav 1995, Lonzi 1985) or volitional control (Zaenen 1993).

This brings us to the second level of differentiation between unergative and unaccusative verbs. Semantically, the unaccusative/unergative distinction has been regarded as being systematically related to the thematic characteristics of the predicate. The Unaccusative Hypothesis was originally formulated in the context of the Universal Alignment Hypothesis (Perlmutter 1978) and later within the Uniformity of Theta Assignment Hypothesis (UTAH), which maintains that, most generally, agent arguments are 'aligned' with syntactic subjects and theme/patient subjects are aligned with syntactic objects (Baker 1988, 1997). Thus, agentivity generally correlates with unergativity, and patienthood with unaccusativity. From a different but complementary angle, split intransitivity has been related to aspectual features, 
particularly telicity, which has been argued by many (e.g., Tenny 1994) to be the crucial determinant of unaccusativity. ${ }^{3}$

However, a lack of correspondence has often been observed between the lexical semantic representation of a verb and the syntactic behavior that might be predicted on the basis of such representation (see Sorace 2000 for an overview). So for example the verbs russare 'snore' and arrossire 'blush', both denoting involuntary bodily processes, select different auxiliaries in Italian; the equivalents of the verb run in many languages can select either auxiliary depending on the context.

These multiple 'unaccusative mismatches' have received very different theoretical explanations. Some theories have abandoned the attempt to characterize split intransitivity semantically (e.g., Perlmutter 1989); others have denied the existence of a syntactic encoding of the distinction (van Valin 1990, Dowty 1991, Lieber \& Baayen 1997). In contrast, some recent models have focused on the nature of syntax/semantics mismatches, maintaining both levels of representation and investigating the interface between the two. These models have demonstrated that most of the diagnostics of unaccusativity/unergativity (such as auxiliary selection in French, impersonal passives in Dutch, resultative constructions in English) tend to identify semantically coherent subsets of verbs. From this perspective, the challenge for a theory of the lexicon-syntax interface is to single out the syntactically relevant components of meaning in different languages. A syntactic characterization of split intransitivity, however, is maintained, since it allows generalizations across phenomena that would be impossible (or purely stipulative) within an exclusively semantic approach.

Within theories of the lexicon-syntax interface, two main perspectives can be distinguished. The 'projectionist' approach (see Levin \& Rappaport Hovav 1996 for discussion) maintains that the lexical semantics of a verb deterministically specifies the hierarchical classification of its arguments, and that this in turn produces the syntactic behavior associated with unaccusativity or unergativity (Hale \& Keyser 1986, 1993, Levin \& Rappaport 1992, 1994, 1995, among others). Within this approach, verbs with variable behavior have different meanings, and therefore different lexical semantic representations, each with its own regular argument structure realization.

Alternatives to the projectionist view that have gained ground in recent years are the 'constructional' approaches (see Borer 1994, 1996, McClure 1995, van Hout 1996, 2000, Arad 1998). These models regard unaccusativity and unergativity not as lexical properties of verbs, but rather as clusters of properties derived from the syntactic configurations in which verbs appear, which in turn determine their aspectual interpretation. Since the lexical entry of verbs does not contain any specification of whether an argument is internal or external, any verb is free to enter into more than one syntactic configuration and consequently to receive multiple aspectual interpretations. This approach, unlike the projectionist model, predicts flexibility in the syntactic realization of arguments, but at the price of overgeneration. Constraints on overgeneration therefore have to be present at other levels; one possibility is to conceive of the mapping as an event-feature checking system (see van Hout 1996).

Evidence that is potentially problematic for the projectionist approach has recently come from a series of studies on auxiliary selection and other reflexes of split intransitivity. Sorace $(1993,1995,2000)$ has provided experimental and developmental data from Italian which indicate that, within the two classes 
of unaccusative and unergative verbs, some verbs require a given perfective auxiliary more categorically than others (see also Bard, Robertson, Sorace 1996). The differential susceptibility of (monadic) intransitive verbs to gradient syntactic behavior is captured by the following hierarchy of semantic verb classes, proposed by Sorace (2000) for the Western European languages that exhibit auxiliary selection:

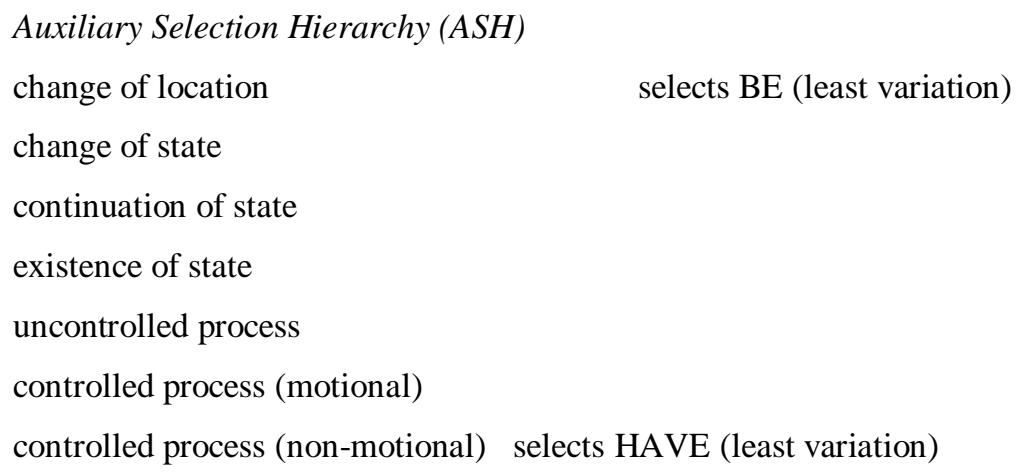

Verbs at the BE end of the Auxiliary Selection Hierarchy are core unaccusatives and denote telic change; verbs at the HAVE end are core unergatives and denote agentive activity in which the subject is unaffected. Intermediate verbs between the two extremes incorporate telicity and agentivity to lesser degrees, and tend to have a less specified (basically stative) event structure. ${ }^{4}$ It is with these intermediate classes of verbs that most cases of 'unaccusative mismatches' or variable mappings are found. Core verbs are those on which native grammaticality judgments are maximally consistent, and are acquired early by both first and second language learners. In contrast, intermediate verbs are subject to crosslinguistic differences and exhibit gradient auxiliary selection preferences. Degree of inconsistency and delay in acquisition are a function of the position of a verb along the hierarchy. The hierarchy embodies both telicity and agentivity but attributes different weight to these factors: telicity is the primary factor, separating be verbs from have verbs and distinguishing subclasses of be verbs; agentivity further differentiates among atelic verbs of process, which are further distinguished by their degree of subject control and affectedness (see Sorace 2000 for details).

The generalization seems to be that as soon as one moves from the core one finds substantial predictable indeterminacy in the syntax-semantics mapping with intransitive verbs. This indeterminacy is difficult to accommodate within a projectionist model of the lexicon-syntax interface, since it would require multiple lexical semantic classifications for a great number of verbs (see van Hout 1996, Rappaport Hovav \& Levin 1996 for discussion).

The Auxiliary Selection Hierarchy makes it possible to predict cross-linguistic variation in auxiliary selection systems: core verbs are predicted to select the auxiliary BE or HAVE across all languages, while intermediate verbs are predicted to exhibit crosslinguistic variation: an intermediate verb class could categorically select BE in one language and HAVE in another. It is also possible that auxiliary selection for intermediate classes is gradient, with the degree of preference for a given auxiliary varying from language to language.

Note that the hierarchy offers a generalization that applies mainly to auxiliary selection, but there is some evidence that other syntactic manifestations of split intransitivity might also be sensitive to this hierarchy, both in languages with and in languages without auxiliary selection (see Sorace 1995 on $n e$ - 
cliticization, Sorace \& Shomura 2001 on Japanese). It therefore has potentially important implications for theoretical accounts of the unaccusative-unergative distinction. Like most recent accounts of unaccusativity (see Alexiadou et al., in press, for a review), the hierarchy seems to point to models that integrate both the structural and the lexical meaning of verbs; it also indicates the necessity to make finer distinctions (both structural and semantic) to explain the systematic variability of verbs.

\subsection{Aims of this Paper}

The main goal of this paper is to investigate the validity of the Auxiliary Selection Hierarchy for German, by examining whether synchronic and crossdialectal variation in auxiliary choice and in impersonal passive formation are sensitive to the position of a verb along the hierarchy. While German data figure in various theoretical discussions of unaccusativity, no systematic experimental investigation of split intransitivity in German has been undertaken before. The focus is on auxiliary selection and impersonal passivization because these are two of the most widely discussed constructions in the literature on split intransitivity in German. Our working hypothesis is that both constructions are valid diagnostics of the unaccusative/unergative distinction to the extent that they broadly differentiate the two classes; however, we expect both constructions to be sensitive to the particular semantic factors represented by the ASH, which means that only specific subsets of verbs may exhibit variation. Furthermore, this paper aims to test the correlation between degrees of cross-dialectal variation in German with respect to auxiliary selection and the position of verbs along the ASH.

While this paper does not attempt to offer a comprehensive alternative model of split intransitivity, it suggests that split intransitivity is a less stable phenomenon than hitherto assumed ${ }^{5}$ further, it provides evidence that a proper account of the variation exhibited by German verbs, while necessarily placed at the lexicon-syntax interface and defined both by structural and by lexical conditions, cannot be either a projectionist model or a constructional model, in the versions currently offered.

The paper is structured as follows. In Section 2, the existing literature on split intransitivity in German is summarized, and the behavior of different verb classes with respect to auxiliary selection and impersonal passivization is described. Sections 3 and 4 present the results of two experiments on the linguistic intuitions of native speakers of German: these experiments investigate the effects of verb class, telicity, and agentivity on auxiliary choice and impersonal passives, as well as the degree of crossdialectal variation in auxiliary selection. Finally, Section 5 includes a discussion of the results and draws some conclusions.

\section{SPLIT INTRANSITIVITY IN GERMAN}

In this section the literature on split intransitivity in German is reviewed, and the semantic factors that have been shown to underpin the distinction are highlighted. Next, the facts about auxiliary selection and impersonal passivization are illustrated with reference to the Auxiliary Selection Hierarchy.

\subsection{Background}


One of the most exhaustive discussions of the relevance of the Unaccusative Hypothesis for German is presented by Grewendorf (1989) from a Government-Binding perspective. Adopting Burzio's (1986) 'ergative hypothesis', Grewendorf shows that a range of phenomena including auxiliary selection, impersonal passivization, extraction processes, topicalization, and reflexivization, provide support for the existence of the syntactic distinction between unaccusative and unergative verbs. ${ }^{6}$

Seibert (1993), in contrast, maintains that the distinction is not syntactically encoded in German. She examines the constructions that Grewendorf regards as diagnostics of unaccusativity and points out that they tend not to correlate and thus do not differentiate neatly between the two classes of verbs. The unreliability of these diagnostics is exemplified by topicalization of the subject and a past participle, which is acceptable with verbs that would otherwise be classified as unergative: ${ }^{7}$

(2) Ein Außenseiter gewonnen hat hier noch nie.

an outsider won has here so-far never

'So far, an outsider never won here.'

(3) Ein Außenseiter hat/*ist gewonnen.

an outsider has/is won

*der gewonnene Außenseiter
the won-PARTICIPLE outsider

Seibert singles out auxiliary selection and the adjectival use of the past participle as 'the only tests that really distinguish between two classes of verb' (1993: 59). However, she regards the existence of these two tests as insufficient evidence in support of a syntactic distinction in German and concludes that all diagnostics actually reflect the presence of certain semantic features in the verb, rather than being the result of the structural position of an argument at the syntactic level. She rejects Levin \& Rappaport Hovav's syntactic-semantic account in terms of linking rules as 'unnecessary'.

Along similar lines, Kaufmann (1995) argues that the different behavior of intransitive verbs in German does not require positing a difference in syntactic representation. Rather, it is a reflection of a semantic distinction between 'object defining properties', which are encoded by D-predicates, and 'optional properties', which are encoded by O-predicates. D-predicates can be further divided into 'dynamic D-predicates' and 'static D-predicates': only the former show 'unaccusative' behavior because they encode a change of an object-defining property; whereas the latter, together with O-predicate, exhibit unergative behavior. O-predicates and stative D-predicates do not form a homogeneous class and are defined negatively as 'non-unaccusative' since they do not encode a property change.

The importance of the semantic factor 'change' for unaccusativity in German is stressed by van Hout, Randall \& Weissenborn (1993), who investigate the nature of the unaccusative/unergative distinction from a learnability perspective. Van Hout et al. adopt Levin \& Rappaport Hovav's (1992) model of linking rules between lexical-semantic components and syntactic realization of arguments, but propose a parameterization of the rule such that the syntactically relevant semantic component for Dutch is telicity, whereas for German it is change (equivalent terms are Brinkmann's (1992) 'transition', and 'locomotion' used by Randall, van Hout, Weissenborn \& Baayen, in press). Positing this parametric difference is necessary, in their view, to account for the fact that Dutch and German select different 
auxiliaries for verbs denoting displacement without a specific endpoint. Compare the following examples from German (see (5a)) and Dutch (see (5b)):

(a) Paul und Rita sind stundenlang durch den Saal getanzt.

Paul and Rita are for-hours though the room danced

'Paul and Rita have been dancing around in the room for hours.'

(b) Paul en Rita hebben urenlang door de zaal gedanst.

Paul and Rita have for-hours though the room danced

'Paul and Rita have been dancing around in the room for hours.'

The difference between Dutch and German is represented by Randall et al. (in press) by means of the following diagram:

\begin{tabular}{lllll}
\multicolumn{1}{c}{ dance } & dance & dance & \\
'BE' into & around & in & 'HAVE' \\
& +endpoint & +locomotion & -locomotion &
\end{tabular}

DUTCH

GERMAN

In an acquisition experiment using novel intransitive verbs, van Hout et al. (1993) show that telicity indeed is the only relevant factor in the Dutch children's production of zijn 'be'; other factors, such as control, do not play a role in their choice of auxiliary. In another set of experiments conducted with German and Dutch adults and children, Randall et al. (in press) show that telicity is equally crucial to BEselection for both Dutch and German children. However, German adults - unlike Dutch adults - use locomotion as the primary determinant of sein selction, which suggests that this factor is acquired at a later stage.

To summarize this brief overview, existing analyses of split intransitivity in German, like the analyses that have been offered for other languages, are divided according to whether the main explanatory burden is placed on the syntactic configurations onto which the verb projects its arguments, the lexical-semantic features underlying its meaning, or the linking rules mapping the verb's semantic components onto syntactic representations. All analyses point out that German, like many other languages that have been studied, exhibits both predictable regularities and variation which so far has not received a plausible explanation.

\subsection{The Auxiliary Selection Hierarchy in German}

This section focuses on the facts of German auxiliary selection and impersonal passivization from the point of view of the Auxiliary Selection Hierarchy in (1), and provides the background for the hypothesis that both the systematicity and the variation in the data can be accounted for in terms of the ASH.

\subsubsection{Auxiliary Selection}


CHANGE OF LOCATION Verbs denoting a change of location are inherently telic and tend to select BE in all languages that have a choice of perfective auxiliary (see Sorace 2000). In German, they strongly select the auxiliary sein 'be'. Class members include the verbs kommen 'come', flüchten 'flee', abreisen 'depart', and entkommen 'escape', as illustrated in (6). Most of these verbs can take a prefix, such as $a b$-, an-, or auf- (see Seibert 1993).

(6) Der Gefangene ist/*hat schnell entkommen.

the prisoner is/has quickly escaped

'The prisoner escaped quickly.'

The auxiliary selection behavior of change of location verbs is not influenced by the aspectual characteristics of the predicate. The auxiliary remains sein, even if the predicate occurs with a modifier like stundenlang 'for hours' such as in (7), resulting in an iterative interpretation of a telic verb.

$$
\begin{aligned}
& \text { Es sind/*haben stundenlang Gefangene entkommen. } \\
& \text { it are/have for-hours prisoners escaped }
\end{aligned}
$$

'Prisoners escaped for hours.'

CHANGE OF STATE Verbs in this class denote a change of state other than a change of location. Change of state verbs can be inherently telic, such as versterben 'die' or verschwinden 'disappear', or they can denote an indefinite change of state with no explicit endpoint, e.g., wachsen 'grow' or steigen 'increase' (see Bertinetto \& Squartini 1995, Hay, Kennedy \& Levin 1999, Sorace 2000, for discussion of these verbs). Auxiliary selection in many languages is sensitive to the presence vs. absence of encoded telicity. In Italian and Dutch, verbs of indefinite change select BE but are less categorical than inherently telic verbs; in French, only inherently telic verbs select être 'be'. Both classes select sein in German.

Das Kind ist/*hat schnell gewachsen.

the child is/has quick grown

'The child grew quickly.'

(b) Der Großvater ist/*hat unerwartet verstorben.

the grandpa is/has unexpectedly died

'The grandfather died unexpectedly.'

Note that change of state verbs are not sensitive to an iterative reading of the predicate:

(9) Die Temperatur ist/*hat drei Stunden lang gestiegen, dann ist/*hat

the temperature is/has three hours long risen then is/has

sie wieder gefallen.

it again fallen

'The temperature rose for three hours, then it fell again.'

German also has a productive sub-class of change of state verbs that are formed by attaching a prefix such as $e r$ - and ver- to a verb stem denoting an atelic process, or an indefinite change. The prefix denotes a change of state and has a telicizing effect on the stem (Seibert 1993, Abraham 1986, van Hout 1996, 2000). Prefixed verbs, unlike the verb stems, strongly select sein.

(10) (a) Der Mann hat geblutet. 
the man has bled

'The man has bled.'

(b) Der Mann ist verblutet.

the man is bled

'The man bled to death.'

(11) (a) Die Blume hat geblüht.

the flower has bloomed

'The flower blossomed.'

(b) Die Blume ist verblüht.

the flower is bloomed

'The flower finished blossoming.'

As van Hout (1996, 2000) shows within an event semantics framework (initially proposed by Pustejovsky 1995, Pustejovsky \& Busa 1995), the particle fixates the telicity of the event via a mechanism of composition that combines the event type of the predicate with that of the particle. This procedure forms a transition from a process to a resulting state and creates a complex predicate, which is illustrated in (12):

(12) Event type composition applied to bluten 'bleed' and prefix ver-:

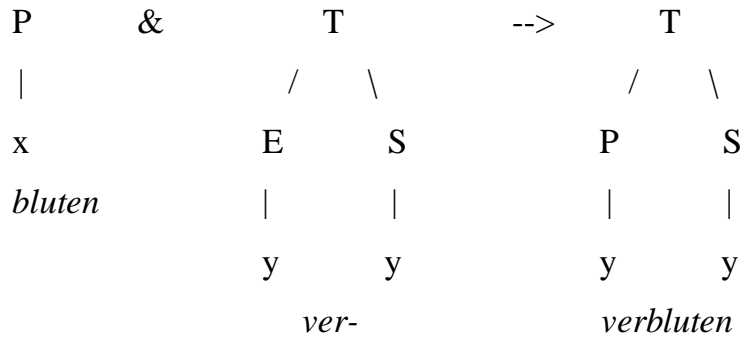

This approach assumes that particles and prefixes contribute their own event structure specification to the mechanism of event type composition, which thus extends to the domain of morphology (for extensive discussion of these issues, see van Hout 1996, 2000).

Continuation of State The verbs in this class denote the continuation of a pre-existing state. As such, they encode the negation of change and are thus different from purely stative verbs (Dahl 1987). Examples include überleben 'survive', dauern 'last', verweilen 'stay', and verharren 'persist'. These verbs prefer the auxiliary haben 'have' in German, although they display some variation:

(13) Der Wanderer ?ist/hat kurz verweilt.

the hiker is/has briefly stayed

'The hiker stayed briefly.'

The auxiliary sein is not completely unacceptable with verbs of this class, consistent with evidence from other languages. A subset of verbs of continuation of state actually prefer sein:

(14) Der Wanderer ist/*hat kurz geblieben.

the hiker is/has briefly remained

'The hiker stayed briefly.' 
This subset includes bleiben 'remain' and its derivatives (zurückbleiben 'stay behind', dableiben 'stay put', etc.). Sorace (2000) points out that 'remain' type verbs also show exceptional auxiliary selection behavior in French and Dutch (see also Lieber \& Baayen 1997, Cummins 1996).

EXISTENCE OF STATE Verbs in this class are purely stative, i.e., do not encode a change at all. They can denote either a concrete physical state, as existieren 'exist', bestehen 'be the case', or sein 'be', or a psychological state, as scheinen 'seem', gefallen 'please', or ausreichen 'suffice'. Both verb types select haben in German.

the book has/is me pleased

'I liked the book.'

(b) Die Dinosaurier haben/*sind wirklich existiert.

the dinosaurs have/were really existed

'The dinosaurs really existed.'

An exception is sein 'be', which takes sein as its auxiliary; this verb also shows exceptional behavior in Dutch and French.

Moreover, the existence of state category also includes verbs denoting the maintenance of a position like sitzen 'sit', stehen 'stand', hocken 'squat', or knieen 'kneel'. These positional verbs tend to select haben but exhibit variation, i.e., they allow both auxiliaries to a certain extent.

$$
\text { Die Betende ?ist/hat würdevoll gekniet. }
$$

the praying-person is/has with-dignity kneeled

'The praying person kneeled with dignity.'

This variation can be regarded as reflecting the fact that verbs in this class can be conceptualized in different ways. Levin \& Rappaport Hovav (1995) distinguish three meanings for positional verbs in English: an 'assume position' meaning (John stood up), a 'maintain position' meaning (John stood on the platform for two hours) and a 'simple position' meaning (The statue stood in the park). While positional verbs are lexically ambiguous in English, the assume position reading in standard German necessarily requires a reflexive pronoun, as illustrated by the contrast below:

Das Kind ?ist/hat auf den Boden gehockt. the child is/has on the floor squatted 'The child squatted on the floor.'

(b) Das Kind *ist/hat sich auf den Boden gehockt. the child is/has SELF on the floor squatted 'The child squatted down on the floor.'

Note that reflexive verbs categorically select haben in German. ${ }^{8}$ The ambiguity of non-reflexive positional verbs is due to the fact that they have a preferred maintain position reading when the subject is animate and a preferred simple position reading if the subject is inanimate (animacy effects are the subject of Experiment 2, see Section 4.1). 
Kaufmann (1995) comments that the difference between standard German (see (18a)) and the southern dialects (see (18b)) is that the latter allow a morphologically identical (non-reflexive) inchoative variant of positional verbs:

Albert hat sich auf den Boden gelegt.

Albert has SELF on the floor laid

'Albert lay down on the floor.'

(b)

Dä Albert isch uff dä Boddä glägge

the Albert is on the floor laid

'Albert lay down on the floor.'

The greater tolerance towards sein with these verbs in standard German may thus be in part due to this dialectal influence.

UNCONTROLLED PROCESS The verbs in this class share the property of referring to non-volitional processes, i.e., processes not controlled by the subject. Two subclasses can be distinguished. The first class contains verbs of involuntary reaction either not involving motion (e.g., schaudern 'shudder', zittern 'shiver', and beben 'tremble'), or involving motion (e.g., torkeln 'totter', taumeln 'stagger', or wackeln, 'wobble'). According to Levin (1993), totter is a verb of body-internal motion which, in isolation, does not entail displacement, although it can assume this reading in the presence of a directional phrase. Both classes of verbs select haben, although not with equal strength:

the woman is/has fearfully shivered

'The woman shivered with fear.'

(b)

Die Frau ?ist/hat etwas getorkelt. the woman is/had a-bit tottered

'The woman tottered a bit.'

Verbs of involuntary reaction involving motion can be telicized by adding a directional adverbial. They then behave like verbs of directed motion and select sein.

(a)
Die Frau *ist/hat in der
Wohnung getorkelt.
the woman is/has in the-DAT flat
tottered

'The woman tottered in the flat.'

(b) Die Frau ist/*hat in die Wohnung getorkelt. the woman is/has in the-ACC flat tattered

'The woman tottered into the flat.'

The second class of uncontrolled process verbs includes verbs of sound emission such as rumpeln 'rumble', brummen 'buzz', and klappern 'rattle'. These verbs typically select haben:

(21) Der Zug *ist/hat laut gerumpelt.

the train is/has noisily rumbled

'The train rumbled noisily.' 
Like in English (see Levin \& Rappaport Hovav 1995), verbs of this class can be telicized by adding a directional adverbial expressing telicity, such as in den Bahnhof 'into the station' (see (22b)). In this case, the verb is interpreted as a directed motion verb (where the motion is concomitant with the sound emission), and we find a preference for sein. In the presence of a positional adverbial such as im Bahnhof 'in the station', we get an atelic interpretation and a haben preference (see (22a)).

(a)

Der Zug *ist/hat im

Bahnhof gerumpelt.

the train is/has in-the-DAT station rattled

'The train rattled in the station.'

(b)
Der Zug ist/*hat in den
Bahnhof gerumpelt.

the train is/has in the-ACC station rattled

'The train rattled into the station.'

These auxiliary alternations indicate that uncontrolled process verbs are sensitive to compositional factors contributed by the sentence in which they appear.

Controlled Process (Motional) Verbs in this class are atelic: they denote a process of non-directed displacement and describe manner of motion. The subject of these verbs is both a volitional initiator and an experiencer of the process. Motion verbs are generally unergative in French, Italian, and Dutch, and select HAVE. In German, however, motion verbs tend to select sein in the absence of a directional adverbial; according to some authors (Seibert 1993), they are in free variation:

(a)

Die Frau ist/?hat schnell geschwommen.

the woman is/has rapidly swum

'The woman swam rapidly.'

(b)

Die Nachbarin ist/?hat langsam geschlurft.

the neighbor is/has slowly shuffled

'The neighbor shuffled slowly.'

(c)

Die Tänzerin ist/?hat langsam getanzt.

the dancer is/has slowly danced

'The dancer danced slowly.'

These verbs select sein more definitely if the predicate has a telic reading; consider the contrasts between (24a) and (24b):

(24) (a) Die Frau ?ist/hat im Fluss geschwommen.

the woman is/has in-the river swam

'The woman swam in the river.'

(b) Die Frau ist/*hat ans Ufer geschwommen.

the woman is/has to-the shore swum

'The woman swam to the shore.'

For controlled process (motional) verbs such as schwimmen 'swim', a directional adverbial induces an auxiliary preference for sein (see (24b)), while a locative adverbial induces a weak preference for haben 
(see (24a)). The lack of categorical preferences for haben for these verbs is consistent with Randall et al.'s (in press) interpretation that puts the factor 'locomotion' at the basis of sein selection (see Section 2.1 above).

Controlled Process (Non-Motional) Verbs in this class denote non-motional, agentive processes and tend to select HAVE consistently across languages. Examples include reden 'talk', warten 'wait', telefonieren 'phone', or arbeiten 'work'. These verbs strongly choose haben in German:

$$
\begin{aligned}
& \text { Die Lehrerin *ist/hat dauernd geredet. } \\
& \text { the teacher is/has continuously talked } \\
& \text { 'The teacher talked continuously.' }
\end{aligned}
$$

To sum up, auxiliary selection in German appears to be sensitive to the ASH in similar ways as other languages with an auxiliary selection system: sein or haben are categorically required with core verbs and alternate to varying extents with intermediate verbs. However, there are certain intermediate verb classes that show auxiliary selection behavior that is the opposite of what we find in other languages. A striking example is the class of verbs of motion, which tend to allow sein even in the absence of a directional phrase that telicizes the predicate.

\subsubsection{Impersonal Passives}

On purely syntactic grounds, impersonal passivization is predicted to be possible only with unergative verbs, since they have an external argument. ${ }^{9}$ However, it has been observed in the literature that impersonal passivization is disallowed by some unergative verbs (see Seibert 1993, Kaufmann 1995 for German, Zaenen 1993 for Dutch). Seibert gives the example sentences in (26):

$$
\begin{aligned}
& \text { Es wurde (*von dem Bild) an der Wand gehangen. } \\
& \text { it was by the picture at the wall hung }
\end{aligned}
$$

'There was a picture hanging at the wall.'

$$
\begin{aligned}
& \text { Es wurde (*von Peters Händen) gezittert. } \\
& \text { it was by Peter's hands shivered } \\
& \text { 'Peter's hands were shivering.' }
\end{aligned}
$$

Verbs such as hängen and zittern are normally classified as unergative. This anomalous behavior indicates, that the presence of a subject that is an agent (the syntactic prerequisite for impersonal passivization) is not sufficient by itself to guarantee the acceptability of the construction: the semantic condition of control is also involved.

Kaufmann (1995) also argues that the same verb can be more acceptable in the impersonal passive construction if the subject is human and agentive. Consider the contrast in (27):

(a) Bei Jazzkonzerten sitzen die Zuschauer meistens, aber auf at jazz-concerts sit the audience mostly but at Rockkonzerten wird eigentlich immer gestanden. rock-concerts was actually always stood 'At jazz concerts, the audience typically sit, while they stand at rock concerts.' 
(b) ??Im Lager liegen die Fahnenstangen normalerweise, aber

in-the storage lie the flagpoles normally but

auf Plätzen wird immer gestanden.

on squares was always stood

'In storage, flag posts typically lie, while on squares they stand.'

Zaenen (1993) and Levin \& Rappaport Hovav (1995) argue that impersonal passivization is not a reliable test of split intransitivity, since it fails to identify all and only unergative verbs. The generalization is that verbs whose subject is an agent are felicitous in the impersonal passive, whereas verbs whose subject is a causer (i.e., a non-volitional initiator; see Arad 1998 for discussion of the distinction between agents and causers) are not. We take the view that these discrepancies are difficult to explain within a purely syntactic model of split intransitivity, but there is no reason why they could not receive an explanation at the lexicon-syntax interface: our starting point is the assumption that variability in impersonal passivization is not significantly different from variability in other diagnostics of split intransitivity. ${ }^{10}$

In general, impersonal passivization is expected to be more acceptable with unergative verbs because agentivity is a relevant feature of these verbs. The acceptability of impersonal passives with atelic verbs denoting a process can be expected to vary according to the degree of agentivity, which increases in the following examples from (28a) to (28d), correlating with an increase in acceptability of impersonal passives:

(a) Uncontrolled Process (Involuntary Reaction)

*Es wurde angstvoll gezittert.

it was fearfully shivered

'There were people shivering with fear.'

(b) Uncontrolled Process (Emission)

?Es wurde laut gerumpelt.

it was loudly rattled

'There was loud rattling.'

(c) Controlled Process (Motional)

?Es wurde schnell geschwommen.

it was quickly swam

'There were people swimming quickly.'

(d) Controlled Process (Non-Motional)

Es wurde dauernd geredet.

it was continuously talked

'There were people talking continuously.'

Agentivity, as pointed out in Section 1, is not a relevant factor for verbs denoting transitions and states (Sorace 2000). In addition, these verbs, being normally unaccusative, do not satisfy the syntactic requirement for passivization, i.e., the presence of an external argument. However, Zaenen (1993) points out that impersonal passives in Dutch are also sensitive to aspectual differences and tend to be more felicitous when the situation described by the predicate is atelic. If the degrees of telicity ${ }^{11}$ expressed by 
the hierarchy are taken into account, then it is plausible to expect variation in degree of unacceptability (rather than acceptability) of impersonal passives with these verbs. Telicity decreases in the following examples from (29a) to (29d), correlating with an increase of acceptability of impersonal passives:

(a) Change of Location

*Es wurde schnell entkommen.

it was fast escaped

'There were people escaping quickly.'

(b) Change of State

*Es wurde langsam errötet.

is was slowly blush

'There were people blushing slowly.'

(c) Continuation of State

?Es wurde kurz verweilt.

it was briefly stayed

'There were people staying briefly.'

(d) Existence of State (Positional)

?Es wurde würdevoll gekniet.

it was with-dignity kneeled

'There were people kneeling with dignity.'

In conclusion, impersonal passivization, like auxiliary selection, shows a sensitivity to thematic roles and telicity which remains unexplained in purely syntactic accounts of split intransitivity and cannot be easily accounted for within a projectionist model of the lexicon-syntax interface. Borer's version of the constructional model, on the other hand, extends to passivization the same treatment that is applied to intransitive verbs: in principle, any argument can project to the configuration that results in the passive interpretation, since there is no information about syntactic projection at the level of lexical entries. ${ }^{12}$ As in the case of the 'unaccusative' or 'unergative' configurations, this overgeneration has to be constrained in some way by ruling out incompatible matches between structural configurations and lexical meanings.

\subsection{Dialectal Variation}

Sorace's (2000) account predicts crosslinguistic variation in the unergative/unaccusative behavior of intermediate, but not of core verbs. Under the assumption that dialect variation is an instance of crosslinguistic variation, we would expect the auxiliary selection behavior of intermediate verbs to be subject to dialectal differences, while the auxiliary selection behavior of core verbs should be stable across dialects. Data from dialects of German is only mentioned in passing by Haider \& Rindler-Schjerve (1987), who observe that the verbs sitzen 'sit', liegen 'lie', and stehen 'stand' select haben in northern varieties of German, while they select sein in southern varieties (Bavarian and Austrian dialects). All three verbs are existence of state verbs, i.e., they are intermediate verbs for which crosslinguistic variation is expected under Sorace's (2000) account. (Note that most existence of state verbs select hebben 'have' also in Dutch.) Dialect differences have also been observed for other intermediate classes, such as the 
controlled process (motional) class (Grewendorf 1989: 10): verbs like schwimmen 'swim', wandern 'hike', or rennen 'run' seem to select haben in southern dialects, while they prefer sein in northern dialects. (See also Section 2.1 for a short discussion of dialect variation with positional verbs.) However, no systematic study of the differences in auxiliary preferences across varieties of German has been conducted. In the following, we will present the results of two experiments that elicit judgments from speakers of northern and southern German, allowing us to assess the claims that have been made in the literature concerning dialect differences in auxiliary selection behavior.

\section{EXPERIMENT 1: EFFECT OF Verb Class on AuXILIARy SElECtion AND IMPERSONAl PASSIVIZATION}

Two experiments were conducted to investigate auxiliary selection and impersonal passive formation in German and to establish whether there is variation between different dialects with respect to these phenomena.

Experiment 1 elicited magnitude estimation judgments on auxiliary selection and impersonal passivization for different verbs along the Auxiliary Selection Hierarchy. The aim was to test Sorace's (2000) claim that core verbs exhibit categorical judgments for auxiliary selection and impersonal passive formation, while intermediate verbs elicit gradient judgments. Data were collected from speakers of two dialectal varieties of German (northern and southern dialects), making it possible to test the additional claim that intermediate, but not core, verbs are susceptible to crosslinguistic (here, crossdialectal) differences.

\subsection{Predictions}

We make four predictions for the present experiment. Our central hypothesis is that auxiliary selection and impersonal passivization are diagnostics for the syntactic distinction between unaccusative and unergative verbs in German, which predicts that:

- $\quad$ sein is overall more acceptable with verbs denoting transitions and states, and haben is overall preferred with verbs denoting atelic processes, and

- impersonal passives are overall more acceptable with verbs denoting atelic processes than with verbs denoting transitions and states.

The second prediction is that the lexical-semantic representation of a verb and its position on the ASH have an influence on its auxiliary selection behavior and on the acceptability of impersonal passivization:

- auxiliary selection is categorical for core verbs in the ASH and gradient for intermediate verbs, and

- impersonal passives are categorically acceptable or unacceptable for core verbs and gradiently acceptable for intermediate verbs, depending on thematic or aspectual features contributed by the sentence in which verbs appear.

As core verbs we consider the verbs that belong to the two classes at the unaccusative extreme and the unergative extreme of the ASH, i.e., change of location verbs and controlled process (non-motional) verbs. For these classes, we predict categorical auxiliary selection behavior, which means that sein is 
significantly more acceptable than haben for change of location verbs, while the reverse is true for controlled (non-motional) process verbs.

The other six classes in the ASH (see (1)) are intermediate classes, and are predicted to be more variable. Gradient auxiliary selection is predicted to occur for these verbs, manifested either as weaker preferences for one auxiliary over the other, or as equal acceptance of both auxiliaries. It is important to note that the ASH does not predict that all intermediate verb classes necessarily display gradience, but only that they are more likely to show gradience. Equally importantly, the ASH does not predict that all languages differentiate among all classes represented by it, but only that languages do not display variation that is inconsistent with the position of a verb along the hierarchy, i.e., with core verbs but not with intermediate verbs. The extent of variation among intermediate verbs is also likely to vary from language to language.

Our third prediction is concerned with cross-dialectal effects, and is based on Sorace's (2000) claim that core verbs are crosslinguisticallly stable in their auxiliary selection behavior, while intermediate verbs exhibit crosslinguistic variation. If we regard dialect variation as an instance of crosslinguistic variation, then speakers of different dialects of German should have the same intuitions regarding the acceptability of auxiliaries for core verbs, while cross-dialectal differences are possible regarding the auxiliary selection for intermediate verbs.

The fourth prediction is that impersonal passive formation should correlate with auxiliary selection behavior. This prediction follows from our assumption that these constructions are diagnostics of the syntactic distinction between unaccusative and unergative verbs. Verbs which select sein should disallow impersonal passives, while verbs which select haben should allow them. This prediction should hold in particular for the core verbs of the change of location class and for the core verbs of the controlled process (non-motional) class. The intermediate verbs in the remaining six classes are expected to exhibit variation, i.e., intermediate acceptability of impersonal passives. These verbs may also exhibit inconsistency between auxiliary selection and impersonal passives. ${ }^{13}$

\subsection{Method}

\subsubsection{Subjects}

Sixty-one native speakers of German participated in the experiment. The subjects were recruited over the Internet by postings to relevant newsgroups and mailing lists. Participation was voluntary and unpaid. Neither linguists nor students of linguistics were allowed to participate.

The data of one subject were excluded because she was bilingual (by self-assessment). The data of another four subjects were excluded because they were linguists (by self-assessment). The data of two subjects were eliminated after an inspection of the responses showed that they had not completed the task adequately. ${ }^{14}$

This left 54 subjects for analysis. Of these, 35 subjects were male, 19 female; eight subjects were left-handed, 46 right-handed. The age of the subjects ranged from 19 to 46 years, the mean was 28.1 years. 


\subsubsection{Materials}

TRAINING MATERIALS The experiment included a set of training materials that were designed to familiarize subjects with the magnitude estimation task. The training set contained six horizontal lines. The range of largest to smallest line was 1:10. The lines were distributed evenly over this range, with the largest item covering the maximal window width of the web browser. We used a line of intermediate length as modulus.

PRACTICE MATERIAls A set of practice items was used to familiarize subjects with applying magnitude estimation to linguistic stimuli. The practice set consisted of six sentences that were representative of the test materials; the practice set contained items with auxiliary selection and impersonal passive constructions (similar to the experimental materials) and items with unrelated constructions (similar to the fillers). A wide spectrum of acceptability was covered, ranging from fully acceptable to severely unacceptable (the acceptability range in the practice items was representative of that in the experimental items). The item used as modulus was a sentence in the middle range, i.e., a sentence that was neither fully acceptable nor full unacceptable.

Test MATERIALS The experiment included two subdesigns. The first subdesign tested auxiliary preferences and crossed the factors verb class (Verb) and auxiliary (Aux). The factor Verb included eight levels, corresponding to the verb classes listed in Table 1. The factor Aux had two levels, sein and haben. This yielded a total of Verb x Aux = 8 x $2=16$ cells. Eight lexicalizations were constructed for each cell, involving the verbs given in Table 1, an animate subject, and an adverb of manner (see the examples in Section 2.1). ${ }^{15}$ The resulting set of materials contained each verb in Table 1 with both haben and sein.

\section{INSERT TABLE 1 ABOUT HERE}

The second subdesign tested the acceptability of impersonal passives, with verb class as the only factor. This factor had the same levels as in the first subexperiment. This time, however, the verbs were embedded in an impersonal passive construction (see (28) and (29)). The same eight lexicalizations as in the first subexperiment were used for each class, creating a total of 64 stimuli. A set of 16 fillers was used, designed to cover the whole acceptability range. As in the practice phase, a modulus item in the middle of the range was used.

To control for possible effects from lexical frequency, the verb classes were matched for frequency. Verb frequencies were obtained from a lemmatized version of the Frankfurter Rundschau corpus (40 million words of newspaper text) and the average verb frequency for each verb class was computed. An ANOVA confirmed that these average frequencies were not significantly different from each other. The corpus frequencies for each verb are listed in Table 1.

\subsubsection{Procedure}


The method used was magnitude estimation as proposed by Stevens (1975) for psychophysics and extended to linguistic stimuli by Bard et al. (1996). Magnitude estimation requires subjects to assign numbers to a series of linguistic stimuli proportional to the acceptability they perceive. First, subjects are exposed to a modulus item, to which they assign an arbitrary number. Then, all other stimuli are rated proportional to the modulus, i.e., if a sentence is three times as acceptable as the modulus, it gets three times the modulus number, etc.

Each subject took part in an experimental session that lasted approximately 15 minutes. The subjects first saw a set of instructions, then they filled in a short demographic questionnaire which was followed by a training phase, a practice phase, and an experimental phase. The experiment was selfpaced, though response times were recorded to allow the data to be screened for anomalies. The experiment was conducted remotely over the Internet, and subjects accessed the experiment using their web browser. The browser established an Internet connection to the experimental server, which was running WebExp 2.1 (Keller, Corley, Corley, Konieczny, \& Todirascu 1998), an interactive software package for administering web-based psychological experiments. Details on the experimental methodology can be found in the appendix, which also contains a discussion of the validity of web-based experimental studies.

INSTRUCTIONS Before the actual experiment started, a set of instructions in German was presented. The instructions first explained the concept of numerical magnitude estimation of line length. Subjects were instructed to make estimates of line length relative to the first line they would see, the reference line. Subjects were told to give the reference line an arbitrary number, and then assign a number to each following line so that it represented how long the line was in proportion to the reference line. Several example lines and corresponding numerical estimates were provided to illustrate the concept of proportionality. Then subjects were told that linguistic acceptability could be judged in the same way as line length. The concept of linguistic acceptability was not defined; instead, examples of acceptable and unacceptable sentences were provided, together with examples of numerical estimates. Subjects were told that they could use any range of positive numbers for their judgments, including decimals. It was stressed that there was no upper or lower limit to the numbers that could be used (exceptions being zero or negative numbers). Subjects were urged to use a wide range of numbers and to distinguish as many degrees of acceptability as possible. It was also emphasized that there were no 'correct' answers, and that subjects should base their judgments on first impressions, not spending too much time to think about any one sentence.

DEMOGRAPHIC QUESTIONNAIRE After the instructions, a short demographic questionnaire was administered. The questionnaire included name, email address, age, sex, handedness, academic subject or occupation, and language region. Handedness was defined as 'the hand you prefer to use for writing', while language region was defined as 'the place (town, federal state, country) where you learned your first language'. 
TRAINING PHASE The training phase was meant to familiarize subjects with the concept of numeric magnitude estimation using line lengths. Items were presented as horizontal lines, centered in the window of the subjects' web browsers. After viewing an item, subjects had to provide a numerical judgment via the computer keyboard. After they pressed Return, the current item disappeared and the next item was displayed. There was no possibility of revisiting previous items or changing responses once Return had been pressed. No time limit was set for either the item presentation or for the response. Subjects first judged the modulus item, and then all the items in the training set. The modulus was the same for all subjects, and it remained on the screen all the time to facilitate comparison. Items were presented in random order, with a new randomization being generated for each subject.

PRACTICE PHASE This phase allowed subjects to practice magnitude estimation of linguistic acceptability. Presentation and response procedure was the same in the training phase, with linguistic stimuli being displayed instead of lines. Each subject judged the whole set of practice items. As in the training phase, subjects first judged the modulus item, and then all the items in the practice set. The modulus was the same for all subjects, and it remained on the screen all the time to facilitate comparison. Items were presented in random order, with a new randomization being generated for each subject.

EXPERIMENTAL PHASE Presentation and response procedures in the experimental phase were the same as in the practice phase. Eight test sets were used: each test set contained one lexicalization for each of the 16 cells in the first subdesign, and one lexicalization for each of the eight cells in the second subdesign, i.e., a total of 24 items. Lexicalizations were assigned to test sets using a Latin square. As in the practice phase, subjects first judged the modulus item, which was the same for all subjects and remained on the screen all the time. Then they saw 40 test items: 24 experimental items and 16 fillers. Items were presented in random order, with a new randomization being generated for each subject. Each subject was randomly assigned to one of the test sets.

\subsection{Results}

The data were normalized by dividing each numeric judgment by the modulus value that the subject had assigned to the reference sentence. This operation creates a common scale for all subjects. Then the data were transformed by taking the decadic logarithm. This transformation ensures that the judgments are normally distributed and is standard practice for magnitude estimation data (Lodge 1981, Bard et al. 1996, Cowart 1997). All analyses were conducted on the normalized, log-transformed judgments. Note also that all the figures in this paper display means of normalized, log-transformed judgments, together with standard errors.

\subsubsection{Auxiliary Selection}

The mean judgments for each verb class for both auxiliaries are graphed in Figure 1. An ANOVA revealed a main effect of $A u x$ (auxiliary), which however was significant only by subjects $(\mathrm{F} 1(1 ; 53)=$ $22.145, p<.0005 ; \mathrm{F} 2(1 ; 7)=2.855, p=.135)$. The main effect of Verb (verb class) was also only 
significant by subjects $(\mathrm{F} 1(7 ; 371)=3.592, p=.001 ; \mathrm{F} 2(1 ; 7)=1.434, p=.213)$. Crucially, a significant interaction of Aux and Verb was obtained $(\mathrm{F} 1(7 ; 371)=72.448, p<.0005 ; \mathrm{F} 2(7 ; 49)=34.891, p<.0005)$. This indicates that auxiliary selection behavior differs between verb classes.

\section{INSERT FIGURE 1 ABOUT HERE}

To further investigate the Aux/Verb interaction, a post-hoc Tukey test was conducted. This test allows us to establish which verb classes exhibit categorical auxiliary selection behavior, i.e., show a significant difference between the acceptability of haben and sein. Recall that we predicted this to be the case for core, but not necessarily for intermediate verbs.

For the verbs of change of location, sein was significantly more acceptable than haben $(p<.01)$, as predicted. The change of state class showed the same behavior $(p<.01)$. The continuation of state class exhibited the opposite pattern: haben was more acceptable than sein $(p<.01)$. For existence of state (positional) verbs there was no significant difference between the acceptability of the two auxiliaries. For the uncontrolled process (involuntary reaction) class, haben was more acceptable than sein, but this difference was only significant by subjects $(p<.01)$. The class controlled process (emission), however, showed a clear unergative pattern: haben was significantly more acceptable than $\operatorname{sein}(p<.01)$. The pattern was reversed for controlled process (motional) verbs, where sein was significantly more acceptable than haben $(p<.01$ by subjects and $p<.05$ by items). Finally, for the verbs of controlled process (non-motional) haben was significantly more acceptable than sein, as predicted $(p<.01)$.

\subsubsection{Impersonal Passives}

The mean judgments for impersonal passives are graphed in Figure 2. A separate ANOVA was conducted for the subexperiment on impersonal passives. A significant main effect of verb class was obtained $(\mathrm{F} 1(7 ; 371)=20.614, p<.0005 ; \mathrm{F} 2(7 ; 49)=10.512, p<.0005)$.

\section{INSERT FIGURE 2 ABOUT HERE}

A post-hoc Tukey test revealed that impersonal passives were significantly less acceptable for change of state verbs than for verbs in all other classes: change of location $(p<.01)$, continuation of state ( $p<.01$ by subjects and $p<.05$ by items), existence of state (positional) $(p<.01)$, uncontrolled process (involuntary reaction) ( $p<.01$ by subjects and $p<.05$ by items), uncontrolled process (emission) $(p<$ $.01)$, controlled process (motional) $(p<.01)$, and controlled process (non-motional) $(p<.01)$. This means that change of state verbs clearly disallow impersonal passivization, and they do so to a greater extent than change of location verbs. This result is not consistent with our prediction.

For controlled process (non-motional) verbs we found that impersonal passives are significantly more acceptable than for verbs in all other classes: change of location $(p<.01$ by subjects and $p<.05$ by items), continuation of state $(p<.01)$, existence of state (positional) $(p<.01)$, uncontrolled process (involuntary reaction) $(p<.01)$, uncontrolled process (emission) $(p<.01$ by subjects only), with the 
exception of the controlled process (motional) verbs. This indicates that controlled process (nonmotional) are the most acceptable with impersonal passives, which is what we predicted.

We also found that impersonal passives were significantly more acceptable for controlled process (motional) verbs than for uncontrolled process (involuntary reaction) verbs $(p<.05$ by subjects only). All other differences did not reach significance.

\subsubsection{Dialectal Variation}

To test the hypothesis that there is crosslinguistic variation in the auxiliary selection behavior of intermediate verbs, but not of core verbs, we divided the subjects into two dialect groups. As part of the personal details questionnaire, subjects had to specify a language region, i.e., the town, federal state, and country where they acquired their native language. Based on these answers we formed two groups: if the language region was in Austria, Switzerland or in a southern German federal state (Bavaria or BadenWürttemberg), then the subject was classified as a speaker of a southern dialect. All other subjects were classified as speakers of northern dialects. (No subjects stated language regions outside Austria, Switzerland, or Germany.) Twenty-six subjects were speakers of southern dialects, the other twenty-eight were speakers of northern dialects. The auxiliary preferences for each verb class for both dialect groups are graphed in Figure 3. Note that this figure does not display absolute judgments, but auxiliary preferences, i.e., the differences between the mean judgments for sein and the mean judgments for haben.

\section{INSERT FIGURE 3 ABOUT HERE}

Based on this classification, we conducted an ANOVA on the auxiliary selection judgments with dialect as a between-subjects variable. This analysis replicated the effects we had found in the overall ANOVA by yielding main effects of $\operatorname{Aux}(\mathrm{F} 1(1 ; 52)=21.741, p<.0005 ; \mathrm{F} 2(7 ; 49)=2.877, p=.134)$ and $\operatorname{Verb}(\mathrm{F} 1(7 ; 364)=3.684, p=.001 ; \mathrm{F} 2(7 ; 49)=1.314, p=.252)$, both significant by subjects only. Also the Verb/Aux interaction was replicated $(\mathrm{F} 1(7 ; 364)=70.094, p<.0005 ; \mathrm{F} 2(7 ; 49)=10.512, p<.0005)$. Crucially, we found a significant three-way interaction between verb class, auxiliary, and dialect $(\mathrm{F} 1(7 ; 364)=2.204, p=.033 ; \mathrm{F} 2(7 ; 49)=2.375, p=.036)$. This interaction demonstrates that dialect has an effect on auxiliary selection behavior, and that this effect differs between verb classes.

As planned comparisons, we carried out separate ANOVAs on the intermediate verb classes for which variation has been attested in the literature, i.e., existence of state (positional) and controlled process (motional) verbs. For existence of state (positional) verbs, we found a significant main effect of auxiliary $(\mathrm{F} 1(1 ; 52)=5.568, p=.022 ; \mathrm{F} 2(1 ; 7)=7.801, p=.027)$, while there was no main effect of dialect. The interaction of auxiliary and dialect was significant by subjects $(\mathrm{F} 1(1 ; 52)=4.089, p=.048$; $\mathrm{F} 2(1 ; 7)=4.805, p=.064)$. This interaction shows that the auxiliary selection behavior of northern speakers is different from the one of southern speakers.

For the controlled process (motional) verbs, we found a significant main effect of auxiliary $(\mathrm{F} 1(1 ; 52)=34.870, p<.0005 ; \mathrm{F} 2(1 ; 7)=5.993, p=.044)$, and no main effect of dialect. A significant interaction of auxiliary and dialect $(\mathrm{F} 1(1 ; 52)=3.902, p=.054 ; \mathrm{F} 2(1 ; 7)=8.078, p=.025)$ was also 
obtained, which again demonstrates that speakers of northern and southern dialects differ in their auxiliary selection preferences for this verb class.

To further investigate the interaction of between verb class, auxiliary, and dialect, we conducted a post-hoc Tukey test on this three-way interaction. This allows us to establish whether verb classes exhibit a categorical auxiliary selection behavior (i.e., show a significant preference for either haben or sein). Recall that we predicted that core verbs show categorical auxiliary selection behavior across dialects, while intermediate verbs are less determinate and can be subject to dialectal variation.

Auxiliary selection was stable across dialects in the core unaccusative class change of location, where we found that sein was preferred over haben in the northern dialect $(p<.01)$ and in the southern dialect $(p<.05)$. Also for change of state verbs, sein was preferred in the northern $(p<.01)$ and the southern dialect $(p<.05)$. There was dialect variation for continuation of state verbs: the judgment of speakers of the northern dialect did not show a significant difference between the two auxiliaries, while speakers of the southern dialect preferred haben $(p<.05)$. As mentioned before, dialect variation was also found for existence of state (positional) verbs, where northern speakers showed a preference for haben ( $p$ $<.05$ by items only), while southern speakers did not prefer either auxiliary. The reverse pattern occurred in the uncontrolled process (involuntary reaction) class, where northern speakers failed to show a significant preference, while southern speakers preferred haben $(p<.05)$. Both northern $(p<.01)$ and southern $(p<.05)$ speakers preferred haben in the uncontrolled process (emission) class, while for controlled process (motional) verbs, northern speakers preferred $\operatorname{sein}(p<.01)$, while southern speakers did not exhibit a significant preference. Finally, the core unergative class controlled process (nonmotional) was crosslinguistically stable: both northern $(p<.01)$ and southern $(p<.05)$ speakers had a strong preference for haben.

\subsection{Discussion}

Overall, the data indicate that the semantic class to which a verb belongs has an influence on auxiliary selection in German. Following Sorace (2000), we distinguished between core verbs and intermediate verbs. As predicted, some intermediate verbs exhibited gradient auxiliary selection behavior and were subject to crossdialectal variation. Core verbs, on the other hand, showed a categorical preference for one auxiliary over the other, and were immune to dialectal variation. We will now discuss the results for each verb class individually.

Recall that as core verbs we defined the verbs in the two classes at the extremes of the Auxiliary Selection Hierarchy. This means that change of location verbs are core unaccusatives, which are predicted to categorically selection sein. This is what we found in Experiment 1. There was no dialect variation for change of location verbs, which is what we expect for this core class.

The results also show that change of state verbs exhibit the same auxiliary selection behavior as change of location verbs in German: they categorically prefer sein and do not show dialect effects. It seems that German speakers combine the two classes of change of location and change of state into a single class of verbs of change. 
Continuation of state verb also fail to show gradience: they significantly prefer haben over sein, and thus behave like unergatives in German. However, we observed dialect effects, namely that only speakers of southern dialects showed a preference for haben, while speakers of northern dialects showed no significant preference for either auxiliary.

For existence of state verbs, we found that auxiliary selection is variable, as there is no overall preference for one auxiliary over the other (see Figure 1). Furthermore, there is a significant dialect effect (see Figure 3). Both findings are compatible with the prediction that existence of state verbs are among the most indeterminate verbs.

Uncontrolled process (involuntary reaction) verbs show an overall weak preference for haben (see Figure 1). The fact that the auxiliary selection preferences are weak (significant by subjects only) is in line with the intermediate status of these verbs, as is the fact that there is dialectal variation: sein is more acceptable for speakers of northern dialects, while speakers of southern dialects fail to show a significant auxiliary selection preference (see Figure 3).

The class uncontrolled process (emission), on the other hand, exhibits a clear preference for haben and fails to trigger dialect effects. Contrary to prediction, this class thus seems to show clear unergative behavior in German.

An interesting case is controlled process (motional) verbs, which show an overall preference for sein, which is consistent with the view that 'locomotion' is a more significant determinant of unaccusativity in German than telicity (see Section 2.1 above). As predicted, there were significant dialect differences in this class: speakers of northern dialect have a stronger preference for sein, while southern speakers have no significant preference for either auxiliary.

Finally, we found that the verbs in the core class controlled process (non-motional) categorically select haben and do not exhibit any dialectal differences, consistent with our hypothesis.

The second major prediction tested in this experiment was that impersonal passive formation correlates with auxiliary selection behavior. This prediction was born out for change of state verbs, which categorically select sein and strongly disallow impersonal passives, and for controlled process (nonmotional) verbs, which categorically select haben and clearly allow impersonal passives. Contrary to prediction, however, change of location verbs showed intermediate acceptability for impersonal passives. A possible explanation is the fact that change of location verbs were presented with agentive subjects, and agentivity is of primary relevance with respect to impersonal passivization, as shown in the literature. Auxiliary selection, on the other hand, does not seem to be sensitive to agentivity.

The controlled process (motional) class also behaved in an unexpected way: the auxiliary selection data showed a preference for sein (typical of unaccusatives), while the impersonal passives were highly acceptable (typical of unergatives).

The verbs in the other four classes (continuation of state, existence of state, uncontrolled process (involuntary reaction), uncontrolled process (emission)) showed intermediate acceptability values for impersonal passives, which is what we predicted for intermediate verb classes.

\section{EXPERIMENT 2: PRoBing the EFFECT OF AgENTIVITY AND TELICITY}


Experiment 1 provided evidence for the distinction between core and intermediate verbs, based on the Auxiliary Selection Hierarchy (see (1)). It demonstrated that the auxiliary selection behavior of core verbs is categorical and stable across dialects. For some intermediate verbs, we found that the auxiliary selection behavior is gradient (i.e., the existence of state class and the uncontrolled process (involuntary reaction) class) or subject to crossdialectal variation (i.e., the existence of state class and the controlled process (motional) class). Other classes that were predicted to show degrees of indeterminacy, however, failed to show gradience or crossdialectal variation (i.e., verbs of change of state, continuation of state, uncontrolled process (emission)).

We conducted a follow-up experiment in order to further investigate the behavior of intermediate verbs and address possible causes for the absence of gradience found in Experiment 1 . This was deemed necessary on theoretical grounds. As indicated in Section 1.1, the ASH incorporates the twofold assumption that (a) while telicity is the main factor that separates BE verbs from HAVE verbs; agentivity is a secondary factor that further distinguishes among BE verbs; and (b) auxiliary selection with core verbs is exclusively determined by the inherent lexical-aspectual features of the verb and is insensitive to other characteristics of the verb itself or the predicate. As one moves away from the core, one finds verbs that are less determinate at the level of aspectual features and increasingly sensitive to other features contributed by sentence in which the verb appears. This is what has been found in other languages (Levin and Rappaport Hovav 1995; Sorace 2000). For instance change of state verbs may allow an indefinite change reading as well as an endpoint, telic reading, depending on the presence of certain adverbial modifiers or, in Germanic languages, certain prefixes; continuation of state verbs, existence of state and positional verbs, as well as other non-core verbs, are in some languages sensitive to the agentivity of the subject, preferring HAVE with agentive subjects and BE with non-agentive ones. Experiment 1 did not test the sensitivity of intermediate verbs to non-lexical verbal features; Experiment 2 was therefore designed to focus on the effects of such features. At the same time, Experiment 2 was designed to replicate the main findings of Experiment 1, namely the lack of variation and the consistent syntactic behavior of core verbs. ${ }^{16}$

The following section explains the modified set of verbs that was employed in Experiment 1.

\subsection{Background}

Change of State Change of state verbs showed a clear preference for sein in Experiment 1. The failure to find the gradience that we expected for this verb class might be due to the fact that the change of state verbs included in Experiment 1 are mainly verbs that denote a telic change with a definite endpoint, such as erscheinen 'appear' or erblassen 'become pale'. Only a few verbs that refer to an incremental change (such as wachsen 'grow') were part of the stimulus set (see also Table 1). To test the hypothesis that telicity is a criterial factor, we used a different set of change of state verbs in Experiment 2: we included only verbs that clearly denote an indefinite change, such as rosten 'rust' or blühen 'blossom'. As pointed out in Section 2.1, many verbs of indefinite change allow prefixing, which induces a telic reading. As further examples, consider (30) and (31). In the unprefixed (a) variants, the verb has an atelic incremental 
change reading, while the prefix in the (b) variant induces an telic reading that implies a definite endpoint of the change.

(30) (a)

Die Dose ?ist/hat gerostet.

the can is/has rusted

'The can rusted.' (focus on the process of rusting)

(b) Die Dose ist/*hat verrostet.

the can is/has rusted

'The can finished rusting.' (focus on the resulting state)

(31) (a) Die Rose ?ist/hat geblüht.

the rose is/has blossomed

'The rose blossomed.' (focus on the process of blossoming)

(b) Die Rose ist/*hat verblüht.

the rose is/has blossomed

'The rose finished blossoming.' (focus on the resulting state)

The (a) verbs prefer haben, but also allow sein to a certain degree, while the (b) verbs only allow sein. To test this intuition, Experiment 2 included a set of change of state verbs that can occur either in a prefixed or in a non-prefixed from, corresponding to the (a) and (b) examples in (30) and (32) (see Table 2 for details).

CONTINUATION OF STATE Continuation of state verbs showed a clear preference for haben in Experiment 1. However, there is some evidence in the literature on other languages that agentivity is a secondary factor that can have an effect on auxiliary selection with continuation of state verbs, as shown by Sorace (2000) for Italian. For example, the Italian verb durare 'last' has a preference for essere 'be' when the subject is inanimate (e.g., La guerra e' durata dieci anni 'The war lasted ten years'), but a preference for avere 'have' when the subject is human (e.g., Il presidente ha durato dieci anni 'The president lasted for ten years'). For some speakers at least, an animacy effect seems to exist also for continuation of state verbs in German, although in the opposite direction from Italian; consider the examples in (32):

$$
\begin{aligned}
& \text { Der Wanderer ?ist/hat kurz verweilt. } \\
& \text { the hiker is/has briefly stayed } \\
& \text { 'The hiker stayed briefly.' }
\end{aligned}
$$

$$
\text { Der Regen *ist/hat kurz angedauert }
$$

the rain is/has briefly lasted

'The rain lasted briefly.'

For animate subjects as in (32a), some speakers have a preference for haben, but sein does not seem to be completely unacceptable. For inanimate subjects such as in (32b), there seems to be a clear preference for haben and clear dispreference for sein. We tested this intuition in Experiment 2 by including a set of continuation of state verbs with inanimate subjects, which allows comparison with the preferences obtained in Experiment 1 for continuation of state verbs with animate subjects (see Table 2 for details). 
EXISTENCE OF STATE Experiment 1 dealt with positional verbs, a subclass of existence of state verbs. We found evidence for crossdialectal variation of in the auxiliary selection behavior of these verbs; speakers of northern dialects prefer haben, while speakers of southern dialects allow both auxiliaries. The fact that we find dialectal variation for positional verbs confirms the intermediate, non-core status of these verbs. In other languages, positional verbs are subject to animacy effects. In English, for example, Mary stood on the platform has a volitional reading that denotes the act of maintaining a position. The corresponding sentence with an inanimate subject The statue stood in the park, on the other hand, only allow a nonvolitional reading, which simply denotes the position the subject is in.

It is possible that similar effects exist in German. As an example, consider (25), where the animate (a) example, for some speakers, exhibits a preference for haben, while the inanimate (b) example exhibits a preference for sein.

Die Täterin ?ist/hat betreten dagestanden.

the offender is/has sheepishly stood-there

'The offender stood there sheepishly.'

(b)

Der Korb ist/?hat unbeachtet dagestanden.

the basket is/has unnoticed stood-there

'The basket stood there unnoticed.'

Experiment 2 attempts to put this observation to test by employing a set of positional verbs with both animate and inanimate subjects (see Table 2 for details).

UNCONTROLLED PROCESS Verbs denoting uncontrolled, involuntary processes showed gradient auxiliary selection behavior in Experiment 1, with a weak overall preference for haben. On the other hand, an analysis across dialects showed that only southern speakers had a significant preference for haben, whereas for northern speakers both auxiliaries were equally acceptable.

As detailed in Section 2.1, the uncontrolled process (involuntary reaction) class contains two types of verbs, viz., verbs that denote a process involving motion (such as torkeln 'totter' or taumeln 'stagger'), and verbs that do not involve motion (such as schaudern 'shudder' or zittern 'shiver'). ${ }^{17}$ It seems possible that the involuntary non-motion verbs prefer haben, while involuntary motion verbs allow both auxiliaries (see also (19)). If we assume that involuntary motion verbs behave like verbs in the controlled process (motional) class, then we have an explanation for the dialect effect: in Experiment 1, we found that northern speakers have a stronger preference for sein than southern speakers for controlled process (motional) verbs. The same dialect effect was observed for uncontrolled (involuntary reaction) verbs, where northern speakers showed a weaker haben preference than southern speakers. However, this effect was probably attenuated by the fact that non-motion verbs were also included in this class. Experiment 2 removes this potential confound by including a separate class with uncontrolled process, involuntary reaction, non-motional verbs (see Table 2 for details).

Change of Location And Controlled Process (Non-Motional) Change of location and controlled process (non-motional) verbs were included as a control condition in Experiment 2; their close-to- 
categorical auxiliary selection preference gives us a standard against which to compare the auxiliary selection behavior of the other verb classes.

\subsection{Predictions}

The design of Experiment 2 is modeled closely on that of Experiment 1. The aim is to elicit judgments for auxiliary selection and impersonal passive formation in German, based on the refined classification described in the previous section. We summarize the predictions for each verb class:

- Change of location and controlled process (non-motional) verbs are included as a control condition in the present experiment. These two core verb classes elicited categorical judgments in Experiment 1. We predict that this behavior will be replicated in the present experiment.

- For change of state verbs, we predict that adding a prefix will induce a preference for sein, as the prefixed version of a change of state verb induces a telic interpretation. Unprefixed change of state verbs, on the other hand, should allow both auxiliaries, as they permit both a telic and an atelic reading.

- For continuation of state verbs, we predict that the use of inanimate subjects will increase the preference for sein, as agentivity (triggered by the human subject) is expected to correlate with unergativity.

- For existence of state (positional) verbs we expect that the presence of an animate subject will induce a 'maintain position' reading and therefore lead to a preference for haben. For inanimate subjects, however, a non-telic reading should be induced, which should lead to a greater preference for sein.

- For uncontrolled process verbs we expect to find a categorical preference for haben. In Experiment 1 we found gradient behavior for this class (contrary to our predictions), which might be due to the fact that this class included both motional and non-motional verbs, selecting sein and haben, respectively. To test this, the present experiment eliminates motion verbs from the uncontrolled process class.

As in Experiment 1, this experiment elicits judgments from speakers northern and southern dialects of German. We expect that the dialect effects established in Experiment 1 will be replicated.

The second aim of Experiment 2 is to investigate the acceptability of the impersonal passive construction for the verbs in the refined classification. In particular, we want to shed further light on the interaction of agentivity and impersonal passive, based on the generalization in the literature that impersonal passives are more acceptable for animate than for inanimate subjects.

\subsection{Method}

\subsubsection{Subjects}

Seventy-two native Speakers of German from the same population as in Experiment 1 participated in the experiment.

The data of four subjects were eliminated after an inspection of the responses showed that they had not completed the task adequately. The data of another two subjects were excluded because they were 
linguists (by self-assessment). This left 66 subjects for analysis. Of these, 42 subjects were male, 24 female; 58 subjects were right-handed, eight left-handed. The age of the subjects ranged from 15 to 59 years, the mean was 27.5 years.

\subsubsection{Materials}

Training and Practice Materials These were designed in the same way as in Experiment 1.

TeSt MATERIALS In analogy to Experiment 1, the present experiment included two subdesigns. The first subdesign tested auxiliary preferences and crossed the factors verb class Verb and auxiliary Aux. The factor Verb included eight levels, corresponding to the verb classes listed in Table 2. The factor Aux had two levels, sein and haben. This yielded a total of Verb x Aux $=8 \times 2=16$ cells. Eight lexicalizations were generated for each verb class, involving the verbs given in Table 2 and an adverb of manner. Depending on the verb class, the subject was either animate or inanimate, as stated in Table 2. This yielded a total of 128 stimuli.

\section{INSERT TABLE 2 ABOUT HERE}

The second subdesign tested the acceptability of impersonal passives, with verb class as the only factor. This factor had the same levels as in the first subexperiment, but the verbs appeared in the impersonal passive construction. The same eight lexicalizations as in the first subexperiment were used for each class, creating a total of 64 stimuli. A set of 24 fillers was used, designed to cover the whole acceptability range. A modulus item in the middle of the range was used.

The verb classes were matched for frequency using the same procedure as in Experiment 1 . The verb frequencies in the Frankfurter Rundschau corpus are listed in Table 2.

\subsubsection{Procedure}

The method used was magnitude estimation of linguistic acceptability, with the same experimental protocol as in Experiment 1.

Instructions, Demographic Questionnaire, Training and Practice Phase These were designed in the same way as in Experiment 1.

EXPERIMENTAL PhaSe Presentation and response procedures in the experimental phase were the same as in Experiment 1. Eight test sets were used: each test set contained one lexicalization for each of the 16 cells in the first subdesign, and one lexicalization for each of the eight cells in the second subdesign, i.e., a total of 24 items. Lexicalizations were assigned to test sets using a Latin square.

Subjects first judged the modulus item, which was the same for all subjects and remained on the screen all the time. Then they saw 48 test items: 24 experimental items and 24 fillers. Items were 
presented in random order, with a new randomization being generated for each subject. Each subject was randomly assigned to one of the test sets.

\subsection{Results}

The data were normalized as in Experiment 1 and separate ANOVAs were conducted for each subexperiment.

\subsubsection{Auxiliary Selection}

The mean judgments for each verb class for both auxiliaries are shown in Figure 4 (recall that all figures graph the means of normalized, log-transformed judgments with standard errors). An ANOVA revealed a significant main effect of $A u x$ (auxiliary) $(\mathrm{F} 1(1 ; 65)=47.413, p<.0005 ; \mathrm{F} 2(1 ; 7)=10.624, p=.014)$. The main effect of Verb (verb class) was also significant $(\mathrm{F} 1(7,455)=13.062, p<.0005 ; \mathrm{F} 2(7 ; 49)=2.771, p$ $=.017)$. Crucially, a significant interaction of Aux and Verb was obtained $(\mathrm{F} 1(7 ; 455)=85.255, p<.0005$; $\mathrm{F} 2(7 ; 49)=37.475, p<.0005)$. This interaction indicates that the verb classes differ in their auxiliary selection behavior.

\section{INSERT FIGURE 4 ABOUT HERE}

To further investigate the Aux/Verb interaction, a post-hoc Tukey test was conducted in order to establish which verb classes exhibit a categorical auxiliary selection behavior, i.e., show a significant difference between the acceptability of haben and sein.

For the core class change of location, sein was more acceptable than haben $(p<.01)$, consistent with the result of Experiment 1. For the change of state (no prefix) class we did not find a significant difference between the two auxiliaries. For change of state (prefix) verbs, in contrast, sein was significantly more acceptable than haben $(p<.01)$. This confirms our prediction that adding a prefix forces a telic reading for this verb class and therefore induces a strong preference for sein. .

Contrary to prediction, haben was more acceptable than sein for the continuation of state (inanimate) class, just as in Experiment 1, in which the animate variant was tested. Similarly, the existence of state class failed to show a significant difference between the two auxiliaries, both in the animate and the inanimate variant. This indicates that animacy does not have an effect on auxiliary selection for these two verb classes.

For the uncontrolled process (involuntary reaction), haben was more acceptable than sein ( $p<$ $.01)$. Also for the core class controlled process (non-motional), a clear preference for haben was obtained $(p<.01)$.

\subsubsection{Impersonal Passives}

The mean judgments for impersonal passives are graphed in Figure 5. A separate ANOVA was conducted for the subexperiment on impersonal passives, yielding a significant main effect of verb class $(\mathrm{F} 1(7 ; 455)$ $=33.275, p<.0005 ; \mathrm{F} 2(7 ; 49)=7.226, p<.0005)$. 


\section{INSERT FIGURE 5 ABOUT HERE}

A post-hoc Tukey test showed that impersonal passives were significantly less acceptable in the class change of state (prefix) than in the classes change of location ( $p<.01$ by subjects and $p<.05$ by items), existence of state (animate) ( $p<.01$ by subjects and $p<.05$ by items), existence of state (inanimate) $(p<$ .01 by subjects only), uncontrolled process (involuntary reaction) ( $p<.01$ by subjects and $p<.05$ by items), and controlled process (non-motional) $(p<.01)$.

Impersonal passive were also less acceptable for verbs in the class change of state (no prefix) than for verbs in the classes change of location ( $p<.01$ by subjects only), existence of state (animate) ( $p$ $<.01$ by subjects only), uncontrolled process (involuntary reaction) $(p<.01$ by subjects only), and controlled process (non-motional) $(p<.01)$. These results, taken together, suggest that the presence of a prefix does not affect judgments on impersonal passives with change of state verbs: the construction remains unacceptable, as in Experiment 1.

For verbs in the class continuation of state, impersonal passives were less acceptable than for verbs in the classes change of location $(p<.01$ by subjects only), existence of state (animate) $(p<.01$ by subjects only), existence of state (inanimate) $(p<.05$ by subjects only), uncontrolled process (involuntary reaction) ( $p<.01$ by subjects only), and controlled process (non-motional) $(p<.01)$. This result diverges from the result of Experiment 1, in which impersonal passives were found to be acceptable with continuation of state verbs. The difference between agentive subjects in Experiment 1 and non-agentive subjects in Experiment 2 seems to be at the root of this divergence.

Furthermore, we found that impersonal passive were more acceptable for verbs in the controlled process (non-motional) class than for verbs of change of location ( $p<.01$ by subjects only), existence of state (animate) ( $p<.01$ by subjects only), existence of state (inanimate) $(p<.01$ by subjects and $p<.05$ by items), and uncontrolled process (involuntary reaction) $(p<.01)$. Again, this confirms the results of Experiment 1, which shows that impersonal passives are most acceptable for verb in this class. Finally, there is a tendency for impersonal passives to be less acceptable with verbs of existence of state (inanimate) than for verbs of existence of state (animate): although the difference does not reach significance, the tendency is in the expected direction, lending additional support to the correlation between agentivity and impersonal passivization.

\subsubsection{Dialectal Variation}

To test for dialect differences, we divided the subjects in speakers of southern and of northern dialects based on the same criteria as in Experiment 1. Twenty-eight subjects were speakers of southern dialects, thirty-eight were speakers of northern dialects. The auxiliary preferences for each verb class for both dialect groups are graphed in Figure 6. Note that this figure, like Figure 3, displays auxiliary preferences, i.e., the difference between the sein judgments and the haben judgments, rather than the absolute judgments. 
We conducted an ANOVA on the auxiliary selection judgments with dialect as a betweensubjects variable. This ANOVA replicated the significant main effects of $\operatorname{Aux}(\mathrm{F} 1(1 ; 64)=49.162, p<$ $.0005 ; \mathrm{F} 2(1 ; 7)=8.959, p=.020)$ and of $\operatorname{Verb}(\mathrm{F} 1(7 ; 448)=13.842, p<.0005 ; \mathrm{F} 2(7 ; 49)=3.167, p=.008)$ that were found in the overall ANOVA. There was no main effect of dialect. The interaction of verb class and auxiliary was also replicated $(\mathrm{F} 1(7 ; 448)=87.866, p<.0005 ; \mathrm{F} 2(7 ; 49)=36.530, p<.0005)$. Furthermore, we found an interaction of verb class and dialect $(\mathrm{F} 1(7 ; 448)=4.879, p<.0005 ; \mathrm{F} 2(7 ; 49)=$ $2.265, p=.044)$ and an interaction of auxiliary and dialect, significant by items only $(\mathrm{F} 1(1 ; 64)=3.399, p$ $=.070 ; \mathrm{F} 2(1 ; 7)=6.913, p=.034)$. Crucially, we found a significant three-way interaction of auxiliary, verb class and dialect $(\mathrm{F} 1(7 ; 448)=2.991, p=.004 ; \mathrm{F} 2(7 ; 49)=3.991, p=.002)$. This interaction demonstrates that dialect has an effect on auxiliary selection behavior.

\section{INSERT FIGURE 6 ABOUT HERE}

As planned comparisons, we carried out separate ANOVAs on the classes for which we predicted a dialect effect based on the results of Experiment 1, i.e., for the existence of state verbs, both for the animate and inanimate condition. For the class existence of state (animate), we found a significant effect of auxiliary $(\mathrm{F} 1(1 ; 64)=12.153, p=.001 ; \mathrm{F} 2(1 ; 7)=6.241, p=.041)$, while there was no main effect of dialect. A significant interaction of auxiliary and dialect was present $(\mathrm{F} 1(1 ; 64)=17.086, p<$ $.0005 ; \mathrm{F} 2(1 ; 7)=20.152, p=.003)$, which shows that the auxiliary selection preferences of northern speakers are different from those of southern speakers.

The same pattern was found for the class existence of state (inanimate): there as an effect of auxiliary $(\mathrm{F} 1(1 ; 64)=21.796, p<.0005 ; \mathrm{F} 2(1 ; 7)=12.773, p=.009)$, a main effect of dialect which was significant by items only $(\mathrm{F} 1(1 ; 64)=3.431, p=.069 ; \mathrm{F} 2(1 ; 7)=24.478, p=.002)$, and an interaction of auxiliary and dialect $(\mathrm{F} 1(1 ; 64)=15.382, p<.0005 ; \mathrm{F} 2(1 ; 7)=18.820, p=.003)$.

As in Experiment 1, we further investigated the interaction of verb class, auxiliary, and dialect by conducting a post-hoc Tukey test on the three-way interaction. This allows us to establish whether verb classes exhibit a categorical auxiliary selection behavior (i.e., show a significant preference for either haben or sein). For the verbs of change of location, we found that speakers of both dialects significantly preferred sein $(p<.01$ in both cases). The change of state (prefix) class also showed a preference for sein in both dialects ( $p<.01$ in both cases). In contrast, the unprefixed version of the change of state class showed no significant difference between auxiliaries in either dialect.

For the verbs in the continuation of state class, speakers of both dialects showed a preference for haben ( $p<.01$ in both cases). For existence of state (animate) verbs, northern speakers showed a preference for haben $(p<.05$ by subjects and $p<.01$ by items), while southern speakers showed no significant preference. The same situation was found for the existence of state (inanimate) verbs, where northern speakers showed a preference for haben $(p<.01)$, while southern speakers showed no significant preference. We also found that uncontrolled process (involuntary reaction) verbs showed a clear haben preference in both dialects ( $p<.01$ in both cases). Finally, for the class of controlled process (non-motional) haben was preferred in both dialects ( $p<.01$ in both cases). 


\subsection{Discussion}

In Experiment 2 we elicited judgments on auxiliary selection and impersonal passive formation in German, based on the refined classification of verbs described in Section 4.1. One of our aims was to establish whether the telicity effects induced by prefixing verbs in the change of state class has an influence on auxiliary selection. Another question was whether agentivity has an effect on auxiliary selection for continuation of state and existence of state verbs. Recall that an increased sensitivity to agentivity is associated with the intermediate status of these verbs on the Auxiliary Selection Hierarchy. We also included uncontrolled, non-motional process verbs to eliminate a potential confound that was present in this class in Experiment 1. We will discuss the results for each verb class separately.

Change of location verbs were found to categorically select sein in Experiment 1, where they also failed to show dialect differences. Both results were replicated in the current experiment.

For change of state verbs, we predicted that adding a prefix would induce a telic reading, triggering a preference for sein, while in the absence of a prefix both a telic and an atelic reading are possible, leading to less determinate auxiliary selection preferences. This was indeed the result that we obtained. Note that this finding is consistent with the fact that the change of state verbs used in Experiment 1 were all prefixed verbs (see Table 1) and we found a clear sein preference for this verb class. Experiment 2 also confirmed the absence of cross-dialectal variation, both for the prefixed and the unprefixed form of the change of state class.

For continuation of state verbs, we predicted that the use of inanimate subjects would affect auxiliary selection preference, in line with claims in the theoretical literature. This prediction was not borne out; as in Experiment 1, we found a clear haben preference for the continuation of state class. No dialect effects were obtained for this verb class, also in line with the results of Experiment 1.

With regard to existence of state (positional) verbs, we expected an effect of animacy on auxiliary selection preference, since only an animate subject allows a 'maintain position' reading. Again, we failed to find this effect; the auxiliary selection preferences of existence of state verbs with animate and inanimate subjects were not significantly different. Experiment 1 showed dialect differences for the existence of state class, in line with the predictions in the literature. The same dialect effects (i.e., weak preferences for haben in speakers of northern dialects) were found in the present experiment, both for the animate and the inanimate condition.

Recall that we had eliminated verbs of body motion from the class of uncontrolled process (involuntary reaction) verbs. The remaining verbs of uncontrolled process showed a clear preference for haben (see Figure 4). This suggests that the verbs of body motion do not belong to this class, but rather to the class of controlled process (motional) verbs. Furthermore, we failed to replicate the dialect effect found in Experiment 1 for uncontrolled process (involuntary reaction) verbs. This is expected under the assumption that motion verbs (which were excluded in the present experiment) exhibit dialect differences.

Finally, Experiment 2 included controlled process (non-motional) verbs as controls. For this class, we found the same behavior as in Experiment 1: they show a clear haben preference and no dialect differences occur. 
The second aim of the present experiment was to investigate impersonal passive formation for the verbs in the refined classification. In particular, we wanted to clarify the interaction of agentivity (animacy) with impersonal passive formation, based on the prediction in the literature that impersonal passives are more acceptable for agentive than for non-agentive subjects.

As in Experiment 1, the change of location class showed intermediate acceptability for impersonal passives, even though they strongly select sein as an auxiliary and were expected to disallow impersonal passivization. We suggested that this result might be due to the agentivity of the subject with which the verbs in this class were presented.

For change of state class we found that acceptability for impersonal passives was low, both for the prefixed and the non-prefixed condition (even though the two conditions differ in auxiliary selection preference). Both conditions were tested with inanimate subjects, hence this result lends support to the hypothesis that inanimate subjects disallow impersonal passives.

This result is confirmed in the continuation of state class: in Experiment 1 we presented animate subjects with this class and found that impersonal passives were of intermediate acceptability. In Experiment 2, verbs in this class were presented with inanimate subjects were presented, resulting in lower acceptability values for impersonal passives. Again, this confirms the correlation between agentivity and impersonal passives.

For the existence of state class, both animate and inanimate subjects were tested. As noted before, impersonal passives were less acceptable for inanimate subjects, but this difference failed to reach significance (see Figure 5).

The result of Experiment 1 was replicated for the uncontrolled process (involuntary reaction) class; impersonal passives were again of intermediate acceptability.

Finally, we had included the core unergative class controlled process (non-motional), which behaved as in Experiment 1, i.e., impersonal passives were highly acceptable.

\section{CONCLUSIONS}

The starting assumption of this study was that split intransitivity is both syntactically encoded and semantically determined. On the basis of this assumption, the study addressed three main questions. The first was the validity of the Auxiliary Selection Hierarchy for German auxiliary choice and impersonal passivization, two syntactic diagnostics of split intransitivity that have received a lot of attention in theoretical literature. The second was the locus and the extent of variation in auxiliary selection across different dialectal varieties of German, and specifically whether the degree of variation correlates with the position in the ASH. The third was the extent of the correlation between auxiliary selection and impersonal passivization in German, i.e., whether the two tests broadly identify the same syntactic classes of verbs and whether they display variation with respect to the same semantic verb classes, which is what is expected of them if they are syntactic diagnostics of split intransitivity.

The results, on the whole, provide an affirmative answer to the first question. Native speakers' judgments on auxiliary selection are most determinate for core verb types, but there are some differences between German and other languages, such as Italian, for which the ASH has been tested. One difference 
is that German does not differentiate between change of location and telic change of state (induced by a prefix): this is not inconsistent with the prediction of the ASH since not all languages necessarily distinguish among all classes. German, however, shows indeterminacy with respect to verbs of indefinite change (which are not inherently specified for telicity, i.e., non-prefixed), as in many other languages (see Sorace 2000 for examples). Another difference is that the class of motional process verbs selects BE in German, unlike many other languages in which it selects HAVE. Taken together, these results indicate that telicity is one relevant determinant of unaccusative syntax, but not the only one: the factor 'locomotion' or 'spatial transition' also underpins unaccusativity, as pointed out by Randall et al. (in press). The factor 'transition' by itself (i.e., not qualified as spatial) is not sufficient to guarantee the selection of sein, as indicated by the indeterminate behavior of verbs of indefinite change.

Intermediate verbs on the ASH are more variable, but do not exhibit the same pattern as in other languages. Consistent with the ASH, auxiliary selection is most indeterminate with verbs denoting existence of state. Verbs of uncontrolled non-motional process and uncontrolled emission show a preference for haben which is not as strong as that for verbs of controlled, non-motional process - also in line with our prediction. Verbs of continuation of state, however, show a definite preference for haben and no sensitivity to subject agentivity. While we are not able at this stage to offer an explanation for this unexpected result, one can speculate that these verbs are in fact conceptualized in a different way in German, i.e., as processes rather than continuations of a pre-existing state: the ambiguous event structure of these verbs makes them potentially compatible with different conceptualizations (see Dahl 1987).

The global pattern of results provides clear support for the view, defended extensively in the literature, that agentivity is the crucial factor associated with impersonal passivization. Impersonal passivization is overall more acceptable with atelic verbs of process than with verbs of transition and state; among the verbs of process it is most acceptable with verbs of non-motional process, which are characterized on the ASH as the most agentive. Unexpectedly, impersonal passives exhibit intermediate acceptability with change of location verbs (instead of being unacceptable), even though they are the least agentive verb class in the ASH. This result may be due to the fact that these verbs were presented with agentive subjects. Additional evidence for the correlation of impersonal passives with agentivity was provided by Experiment 2, where we found a tendency towards lower acceptance of this construction for existence of state (inanimate) verbs with non-agentive subjects than for verbs in the same class with agentive subjects.

The data show that auxiliary selection and impersonal passivization correlate to some extent, although the correlation is not perfect. We predicted that the strongest correlation would be found for core verbs on the ASH, whereas it would be weaker with intermediate verbs. Overall, this is what we found: with the exception of change of location verbs (which strongly select sein but allow impersonal passives to some extent), the more decisively a verb selects sein, the more it rejects impersonal passives; conversely, the stronger the preference for haben, the more acceptable impersonal passives are. Inconsistencies are found with intermediate verbs: continuation of state verbs, for example, have a clear preference for haben but tend to reject impersonal passives; existence of state verbs are indeterminate with respect to auxiliary selection, but are not rejected as completely ungrammatical in impersonal 
passive constructions. Such inconsistency between diagnostics for intermediate verbs is not incompatible with our predictions, and has indeed been found in other studies (e.g., Legendre 1991 for French).

As for cross-dialectal variation, the results of this study support the prediction that variation is confined to intermediate verb classes on the ASH. In both experiments described in this paper, speakers of northern and southern varieties of German express similar judgments on core verbs and divergent judgments on some of the intermediate verb classes, notably those denoting existence of state, continuation of state, uncontrolled processes, and controlled motional processes. Some of the results are not consistent with our prediction, such as those for the uncontrolled verbs of emission which speakers of both varieties judged in the same way: on the whole, however, the general pattern confirms the greater openness of non-core verbs to both intralinguistic and crosslinguistic variation.

To conclude, the pattern of systematic variation obtained for two syntactic manifestation of split intransitivity in German supports the view that split intransitivity is placed at the lexicon-syntax interface and requires a precise characterization of both levels. It further calls for a theoretical account that combines some of the fine-grained semantic distinctions incorporated in projectionist models with the syntactic mechanisms embodied by constructional models. 


\section{APPEndix: The VALIDITY OF WEB-BASEd EXPERIMENTS}

Experiments 1 and 2 were administered using the World-Wide Web. This mode of experimentation allows rapid access to a large number of speakers (even for less commonly spoken languages). However, there are potential problems with web-based data, as compared to conventional data obtained in a controlled laboratory setting. It has been argued that by using web data, the experimenter can exercise less control over the experimental setting, as each subject might complete the experiment under different conditions, possibly in an environment that includes noise or other distractions. Also, there is an obvious need for making sure that the subjects taking part in the experiment respond in the way intended by the experimenter, i.e., that they understand and follow the experimental instructions properly. A third problem is subject authentication - we have to guarantee that the subject provides genuine data and does not take part more than once in each experiment.

In this Appendix, we will discuss how the experimental software used in Experiment 1 and 2 is designed to address these problems, and summarize the results of a validation study reported by Keller $\&$ Alexopoulou (2001).

\section{Experimental Procedure}

Experiments 1 and 2 were administered using WebExp (Keller et al. 1998), a software package designed for conducting psycholinguistic studies over the web.

WebExp is implemented as a set of Java classes. As Java is a full-fledged programming language, it gives the web designer maximum control over the interactive features of a web site. WebExp makes use of this flexibility to keep the experimental procedure as constant as possible across subjects. An important aspect is that the sequence in which the experimental items are administered is fixed for each subject: the subject does not have the possibility to go back to previous stimuli and inspect or change previous responses. (If the subject hits the 'back' button on the browser, the experiment will terminate.)

Another important feature is that WebExp provides timings of subject responses by measuring onset time and completion time for each response. The studies reported in the present paper make no direct use of these timings, as they only deal with acceptability judgments. Nevertheless the timings are useful to screen the responses for anomalies, i.e., to eliminate the subjects who responded too quickly (and thus probably did not complete the experiment in a serious fashion), or those who responded too slowly (and thus were probably distracted while doing the experiment). WebExp automatically tests the response timings against upper and lower limits provided by the experimenter and excludes subjects whose timings are anomalous. Further manual checks can be carried out on the response timings later on.

\section{Subject Authentication}

Apart from providing response timing, WebExp also offers a set of safeguards that are meant to ensure the authenticity of the subjects taking part, and exclude subjects from participating more than once.

- EMAIL ADDRESS Each subject has to provide their email address. An automatic plausibility check is conducted on the address to ensure that it is syntactically valid. If the address is valid, then WebExp automatically sends an email to this address (containing a message thanking the 
subject for taking part). If the email bounces, the experimenter should exclude this subject from the data set, as they probably used a fake identity.

- Personal Data Before being allowed to start the experiment, each subject has to fill in a short questionnaire supplying name, age, sex, handedness, and language background. These data allow manual plausibility checks to be conducted, and subjects that give implausible answers can be eliminated from the data set. The data on language background can be used to conduct by-dialect analyses, as they were reported in Experiments 1 and 2.

- RESPONSES A manual inspection of the responses allows the experimenter to detect subjects that have misunderstood the instructions and responded in an anomalous fashion, e.g., by giving the same response to every item.

- Connection Data The software also $\log$ s the following data related to the subject's web connection: the internet address of the host machine, the type of computer and operating system, and the web browser the subject is using. This information (in addition to the email address) is valuable in detecting subjects that take part more than once.

Note that taking part in a WebExp study requires a subject to give up their anonymity and supply name and email address. This is a move we consider justified in the interest of ensuring subject authenticity. The experimental web site contains a privacy statement that guarantees that all subject data will be treated strictly confidential.

\section{Comparison with Laboratory Data}

The safeguards outlined in the last section go some way towards ensuring the authenticity of web data by eliminating subjects that are not genuine, that take part more than once, or that misunderstand the instructions. However, the ultimate test of web-based data is a comparison with data obtained using a conventional, lab-based procedure.

Such a comparison is provided by Keller \& Alexopoulou (2001), who present experiments that investigate native speakers' judgments of word order preferences in Greek. They include a validation study that supports the claim that web-based experimental data and laboratory data yield comparable results: separate ANOVAs on the web-based and the lab-based judgments reveal the same significant main effects and interactions. Also, no interaction between the experimental procedure (web or lab) and the experimental factors (word order, clitic doubling, accent placement, and context) is found.

Furthermore, a high correlation between the average judgments obtained with both procedures can be demonstrated. Taken together, these results suggest that there is no relevant difference between webbased and lab-based data for grammaticality judgment data of the type reported by Keller \& Alexopoulou (2001).

We assume that this result carries over to the data in the present experiment, which also relied on grammaticality judgments collected over the web, and employed an experimental methodology that is virtually identical to the one used by Keller \& Alexopoulou (2001). 


\section{REFERENCES}

Abraham, Werner (1986). Unaccusatives in German. In Abraham, Werner (ed.), Groninger Arbeiten zur Germanistischen Linguistik 28. University of Groningen. 1-72.

Alexiadou, Artemis, Anagnostopoulou, Elena, \& Everaert, Martin (eds.) (In press). The unaccusativity puzzle: studies on the syntax-lexicon interface. Oxford: Oxford University Press.

Alsina, Alex (1996). The role of argument structure in grammar: evidence from Romance. Stanford: CSLI Press.

Arad, Maya (1998). VP-structure and the syntax-lexicon interface. MIT Occasional Papers in Linguistics 16. Department of Linguistics and Philosophy, MIT.

Baker, Mark (1988). Incorporation: a theory of grammatical function changing. Chicago: University of Chicago Press.

Baker, Mark (1997). Thematic roles and syntactic structure. In Liliane Haegeman (ed.), Elements of Grammar. Dordrecht: Kluwer. 73-137.

Bard, Ellen Gurman, Robertson, Daniel \& Antonella Sorace (1996). Magnitude estimation of linguistic acceptability. Language 71. 32-68.

Belletti, Adriana. \& Rizzi, Luigi (1981). The syntax of ne: some theoretical implications. The Linguistic Review 1. 117-154.

Bertinetto, Pier Marco \& Squartini, Mario (1995). An attempt at defining the class of gradual completion verbs. In Bertinetto, Pier Marco, Bianchi, Valentina, Higginbotham, James \& Squartini, Mario (eds.), Temporal reference, aspect and actionality. Torino: Roserberg \& Sellier. 11-28.

Borer, Hagit (1994). The projection of arguments. In Benedicto, Elena \& Runner, Jeff (eds.), Functional Projections. Occasional Papers in Linguistics 17. University of Massachusetts, Amherst. 19-48.

Borer, Hagit (1996). Passive without theta-grids. In Steven Lapointe (ed.), Morphological interfaces. Stanford: CLSI Press.

Brinkmann, Ursula (1992). Choice of auxiliary for intransitive verbs of motion: an analysis of an unaccusative diagnostic. Unpublished ms., Max Planck Institute for Psycholinguistics, Nijmegen.

Burzio, Luigi (1986). Italian syntax: a government-binding approach. Dordrecht: Foris.

Cowart, Wayne (1997). Experimental syntax: applying objective methods to sentence judgments. Sage Publications: Thousand Oaks, CA.

Cummins, Sarah (1996). Meaning and mapping. PhD dissertation, University of Toronto.

Dahl, Östen (1987). Case grammar and prototypes. In René Dirven \& Gunter Radden (eds.), Concepts of case. Tübingen: Gunter Narr Verlag. 147-161.

Dowty, David (1991). Thematic proto-roles and argument selection. Language 67. 547-619.

Grewendorf, Günther (1989). Ergativity in German. Dordrecht: Foris.

Grimshaw, Jane (1990). Argument structure. Cambridge, MA: MIT Press.

Hale, Kenneth \& Keyser, Samuel Jay (1986). Some transitivity alternations in English. Lexical Project Working Paper 7, Centre for Cognitive Science, MIT. 
Hale, Kenneth \& Keyser, Samuel Jay (1993). On argument structure and the lexical expression of syntactic relations. In Kenneth Hale \& Samuel Jay Keyser (eds.), The view from building 20: essays in linguistics in honor of Sylvain Bromberger. Cambridge, MA: MIT Press. 53-110.

Haider, Hubert \& Rindler-Schjerve, Rositta (1987). The parameter of auxiliary selection: Italian-German contrasts. Linguistics 25. 1029-1055.

Hay, Jennifer, Kennedy, Christopher, \& Levin, Beth (1999). Scalar structure underlies telicity in degree achievements. Matthews, Tanya \& Strolovitch, Devon (eds.), Proceedings of SALT 9, Cornell Linguistics Circle Publications, Cornell University, Ithaca, NY. 127-144.

Hoekstra, Teun. \& René Mulder (1990). Unergatives as copular verbs; locational and existential predication. The Linguistic Review 7. 1-79.

van Hout, Angeliek (1996). Event semantics of verb frame alternations: a case study of Dutch and its acquisition. PhD dissertation, Tilburg University. Published 1998 by Garland, New York.

van Hout, Angeliek (2000). Event semantics in the lexicon-syntax interface: verb frame alternations in Dutch and their acquisition. In Carol Tenny \& James Pustejovsky (eds.), Events as grammatical objects. Stanford: CSLI Press.

van Hout, Angeliek, Randall, Janet \& Weissenborn, Jürgen (1993). Acquiring the unergativeunaccusative distinction. In Maaike Verrips \& Frank Wijnen (eds.), The acquisition of Dutch. Publikatie nummer 60, Instituut voor Algemene Taalwetenschap, Universiteit van Amsterdam. 79-120.

Kayne, Richard (1993). Toward a modular theory of auxiliary selection. Studia Linguistica 47. 3-31.

Kaufmann, Ingrid (1995). O- and D-predicates: a semantic approach to the unaccusative-unergative distinction. Journal of Semantics 12. 377-427.

Keller, Frank \& Alexopoulou, Theodora (2001). Phonology competes with syntax: experimental evidence for the interaction of word order and accent placement in the realization of information structure. Cognition 79. 301-372.

Keller, Frank, Corley, Martin, Coley, Steffan, Konieczny, Lars, \& Todirascu, Amalia (1998). WebExp: A Java toolbox for web-based psychological experiments. Technical Report HCRC/TR-99, Human Communication Research Centre, University of Edinburgh.

Legendre, Géraldine. 1991. Unaccusativity in French. Lingua 79. 95-174.

Koopman, Hilda \& Sportiche, Dominique (1991). The position of subjects. Lingua 85. 211-58.

Levin, Beth (1993). English verb classes and alternations: a preliminary investigation. Chicago: University of Chicago Press.

Levin, Beth \& Rappaport Hovav, Malka (1992). The lexical semantics of verbs of motion: the perspective from unaccusativity. In Iggy Roca (ed.), Thematic structure: its role in grammar. Dordrecht: Foris.

Levin, Beth \& Rappaport Hovav, Malka (1994). A preliminary analysis of causative verbs in English. Lingua 92. 35-77.

Levin, Beth \& Rappaport Hovav, Malka (1995). Unaccusativity: at the syntax-semantics interface. Cambridge, MA: MIT Press. 
Levin, Beth \& Rappaport Hovav, Malka (1996). From lexical semantics to argument realization.

Unpublished ms., Northwestern University and Bar-Ilan University.

Lewis, Geoffrey L. (1967). Turkish grammar. Oxford: Oxford University Press.

Lieber, Rochelle. \& Baayen, Harald (1997). A semantic principle of auxiliary selection in Dutch. Natural Language and Linguifstic Theory 15. 789-845.

Lodge, Milton (1981). Magnitude scaling: quantitative measurement of opinions. Beverley Hills, CA: Sage Publications.

Lonzi, Lidia (1985). Pertinenza della struttura tema-rema per l'analisi sintattica. In Harro Stammerjohann (ed.), Theme-rheme in Italian. Tübingen: Gunter Narr. 99-120.

McClure, William (1995). Syntactic projections of the semantics of aspect. Tokyo: Hitsujishobo.

Perlmutter, David (1978). Impersonal passives and the unaccusative hypothesis. In Jeri J. Jaeger, Anthony

C. Woodbury, Farrell Ackerman, Christine Chiarello, Orin D. Gensler, John Kingston, Eve E.

Sweetser, Henry Thompson, and Kenneth W. Whitler (eds.), Proceedings of the Fourth Annual

Meeting of the Berkeley Linguistic Society. University of California, Berkeley. 157-189.

Perlmutter, David (1989). Multiattachment and the unaccusative hypothesis: the perfect auxiliary in Italian. Probus 1. 63-119.

Pustejovsky, James (1995). The generative lexicon. Cambridge, MA: MIT Press.

Pustejovsky, James \& Busa, Federica (1995). Unaccusativity and event composition. In Bertinetto et al. (eds.), 159-178.

Randall, Janet, van Hout, Angeliek, Weissenborn, Jürgen, \& Baayen, Harald (In press). Acquiring unaccusativity: a cross-linguistic look. In Alexiadou et al. (eds.).

Rappaport Hovav, Malka \& Levin, Beth (1998). Building verb meanings. In Miriam Butt \& Wilhelm Geuder (eds.), The projection of arguments: lexical and compositional factors. Stanford: CSLI Press. 97-134.

Seibert, Anja (1993). Intransitive constructions in German and the ergative hypothesis. Working Papers in Linguistics 14, University of Trondheim.

Sorace, Antonella (1993). Incomplete vs. divergent representations of unaccusativity in non-native grammars of Italian. Second Language Research 9. 22-47.

Sorace, Antonella (1995). Acquiring argument structures in a second language: the unaccusative/unergative distinction. In Lynn Eubank, Larry Selinker, \& Michael Sharwood Smith (eds.), The current state of interlanguage. Amsterdam: John Benjamins. 153-175.

Sorace, Antonella (2000). Gradients in auxiliary selection with intransitive verbs. Language 76. 859-890.

Sorace, Antonella \& Shomura, Yoko (2001). Lexical constraints on the acquisition of split intransitivity. Studies in Second Language Acquisition 23: 247-278.

Stevens, S. S. (1975). Psychophysics: introduction to its perceptual, neural, and social prospects. New York: John Wiley.

Tenny, Carol (1994). Aspectual roles and the syntax-semantics interface. Dordrecht: Kluwer.

Van Valin, Robert D. (1990). Semantic parameters of split intransitivity. Language 66. 221-260. 
Zaenen, Annie (1993). Unaccusativity in Dutch: Integrating syntax and lexical semantics. In James Pustejovsky (ed.), Semantics and the Lexicon. Dordrecht: Kluwer. 129-161. 
Authors' addresses:

Frank Keller

Institute for Communicating and Collaborative Systems

Division of Informatics, University of Edinburgh

2 Buccleuch Place, Edinburgh EH8 9LW, UK

Phone: +44-131-650-4407

Fax: $+44-131-650-6626$

Email:keller@cogsci.ed.ac.uk

Antonella Sorace

Department of Theoretical and Applied Linguistics

University of Edinburgh

George Square, Edinburgh EH8 9LL, UK

Phone: +44-131-650-3493/3961

Fax: +44-131-650-3962

Email: antonella@ling.ed.ac.uk 


\section{TABLES}

\begin{tabular}{|c|c|}
\hline$n$ & $\begin{array}{l}\text { aufsteigen 'climb' (319), entkommen 'escape' (418), zurückkommen 'come } \\
\text { back' (251), ankommen 'arrive' (989), abreisen 'depart' (65), flüchten 'flee' } \\
\text { (1396), weggehen 'go away' (92), vorrücken 'move forward' (45) }\end{array}$ \\
\hline$\overline{\text { cha }}$ & $\begin{array}{l}\text { erscheinen 'appear' (4709), erblassen 'become pale' (94), nervös werden } \\
\text { 'become nervous' (30), versterben 'die' (127), erröten 'blush' (10), erkalten } \\
\text { 'become cold' (13), wachsen 'grow' (3237), verschwinden 'disappear' (2106) }\end{array}$ \\
\hline$\overline{\text { conti }}$ & $\begin{array}{l}\text { dahinvegetieren 'vegetate' (4), überdauern 'outlast' (53), aushalten 'endure' } \\
\text { (235), weiterexistieren 'continue existing' (5), weiterleben 'continue living' } \\
\text { (54), überleben 'survive' (883), verharren 'persist' (152), verweilen 'stay' (69) }\end{array}$ \\
\hline $\begin{array}{l}\text { existence of state } \\
\text { (positional) }\end{array}$ & $\begin{array}{l}\text { herumstehen 'stand about' (40), herumhängen 'hang } \\
\text { about' (9), knien 'kneel' (43), kauern 'crouch' (91), baumeln 'dangle' (82), } \\
\text { schweben 'hover' (621), sitzen 'sit' (5215), hocken 'squat' (252) }\end{array}$ \\
\hline $\begin{array}{l}\text { uncontrolled process } \\
\text { (involuntary reaction) }\end{array}$ & $\begin{array}{l}\text { torkeln 'totter' (16), taumeln 'stagger' (42), wackeln } \\
\text { 'wobble' (137), schwanken 'wobble' (218), schaudern 'shudder' (18), beben } \\
\text { 'tremble' (89), zittern 'shiver' (215), schlottern 'shiver' (58) }\end{array}$ \\
\hline $\begin{array}{l}\text { uncontrolled process } \\
\text { (emission) }\end{array}$ & $\begin{array}{l}\text { rumpeln 'rumble' (36), klappern 'rattle' (69), brummen } \\
\text { 'buzz' (97), quietschen 'squeak' (26), rattern 'clatter' (49), tuckern 'tap' (42), } \\
\text { surren 'whir' (29), ächzen 'moan' (37) }\end{array}$ \\
\hline $\begin{array}{l}\text { controlled process } \\
\text { (motional) }\end{array}$ & $\begin{array}{l}\text { schwimmen 'swim' (523), wandern 'hike' (815), schlurfen } \\
\text { 'shuffle' (16), rennen 'run' (570), tanzen 'dance' (1265), klettern 'climb' } \\
\text { (905), kriechen 'creep' (101), hüpfen 'hop' (138) }\end{array}$ \\
\hline $\begin{array}{l}\text { controlled process } \\
\text { (non-motional) }\end{array}$ & $\begin{array}{l}\text { reden 'talk' (5083), dozieren 'lecture' (58), plaudern } \\
\text { 'chat' (244), warten 'wait' (4451), mitarbeiten 'collaborate' (400), telefonieren } \\
\text { 'phone' (199), nachgeben 'give in' (257), mitspielen 'play' (359) }\end{array}$ \\
\hline
\end{tabular}

\section{Table 1}

Verb classes and class members used in Experiment 1. The frequency for each verb in the Frankfurter Rundschau corpus is provided in brackets. 


\begin{tabular}{|c|c|}
\hline $\begin{array}{l}\text { change of location } \\
\text { (animate) }\end{array}$ & $\begin{array}{l}\text { aufsteigen 'climb' (319), entkommen 'escape' (418), } \\
\text { zurückkommen 'come back' (251), ankommen 'arrive' (986), abreisen 'depart' } \\
\text { (65), flüchten 'flee' (1396), weggehen 'go away' (92), vorrücken 'move } \\
\text { forward' (45) }\end{array}$ \\
\hline $\begin{array}{l}\text { change of state } \\
\text { (-prefix, inanimate) }\end{array}$ & $\begin{array}{l}\text { rosten 'rust' (39), modern 'rot' (29), faulen 'rot' (14), } \\
\text { schimmeln 'become mouldy' (5), welken 'wilt' (12), blühen 'bloom' (337), } \\
\text { keimen 'germinate' (41), wachsen 'grow' (3237) }\end{array}$ \\
\hline $\begin{array}{l}\text { change of state } \\
\text { (+prefix, inanimate) }\end{array}$ & $\begin{array}{l}\text { verrosten 'rust' (16), vermodern 'rot' (9), verfaulen } \\
\text { 'rot' (15), verschimmeln 'become mouldy' (10), verwelken ‘wilt' (12), } \\
\text { verblühen 'bloom' (7), aufkeinem 'germinate' (11), anwachsen 'grow' (249) }\end{array}$ \\
\hline $\begin{array}{l}\text { continuation of state } \\
\text { (inanimate) }\end{array}$ & $\begin{array}{l}\text { dauern 'last' (3206), andauern 'last' (122), fortdauern } \\
\text { 'last' (7), halten 'last' (18206), anhalten 'continue' (581), reichen 'suffice' } \\
\text { (4590), ausreichen 'suffice' (710), genügen 'suffice' (979) }\end{array}$ \\
\hline $\begin{array}{l}\text { existence of state } \\
\text { (positional, animate) }\end{array}$ & $\begin{array}{l}\text { dastehen 'stand' (184), herumstehen 'stand about' (57), } \\
\text { herumhängen 'hang about' (25), baumeln 'dangle' (83), liegen 'lie' (18725), } \\
\text { herumliegen 'lie about' (43), daliegen 'lie' (8), schweben 'hover' (671) }\end{array}$ \\
\hline $\begin{array}{l}\text { existence of state } \\
\text { (positional, inanimat }\end{array}$ & $\begin{array}{l}\text { dastehen 'stand' (184), herumstehen 'stand about' (57), } \\
\text { erumhängen 'hang about' (25), baumeln 'dangle' (83), liegen 'lie' (18725), } \\
\text { herumliegen 'lie about' (43), daliegen 'lie' (8), schweben 'hover' (671) }\end{array}$ \\
\hline $\begin{array}{l}\text { uncontrolled process } \\
\text { (involuntary reaction, } \\
\text { non-motional, anim.) }\end{array}$ & $\begin{array}{l}\text { schaudern 'shudder' (18), beben 'tremble' (89), zittern } \\
\text { 'shiver' (215), schlottern 'shiver' (58), zucken 'convulse' } \\
\text { (99), gähnen 'yawn' (27), keuchen 'wheeze' (12), schwitzen 'sweat' (161) }\end{array}$ \\
\hline $\begin{array}{l}\text { controlled process } \\
\text { (non-motional, anim.) }\end{array}$ & $\begin{array}{l}\text { reden 'talk' (3083), dozieren 'lecture' (58), plaudern } \\
\text { 'chat' (244), warten 'wait' (4451), arbeiten 'work' (400), telefonieren } \\
\text { 'telephone' (199), nachgeben 'give in' (257), mitspielen 'play' (259) }\end{array}$ \\
\hline
\end{tabular}

Table 2

Verb classes and class members used in Experiment 2. The frequency for each verb in the Frankfurter Rundschau corpus is provided in brackets. 
FIGURES

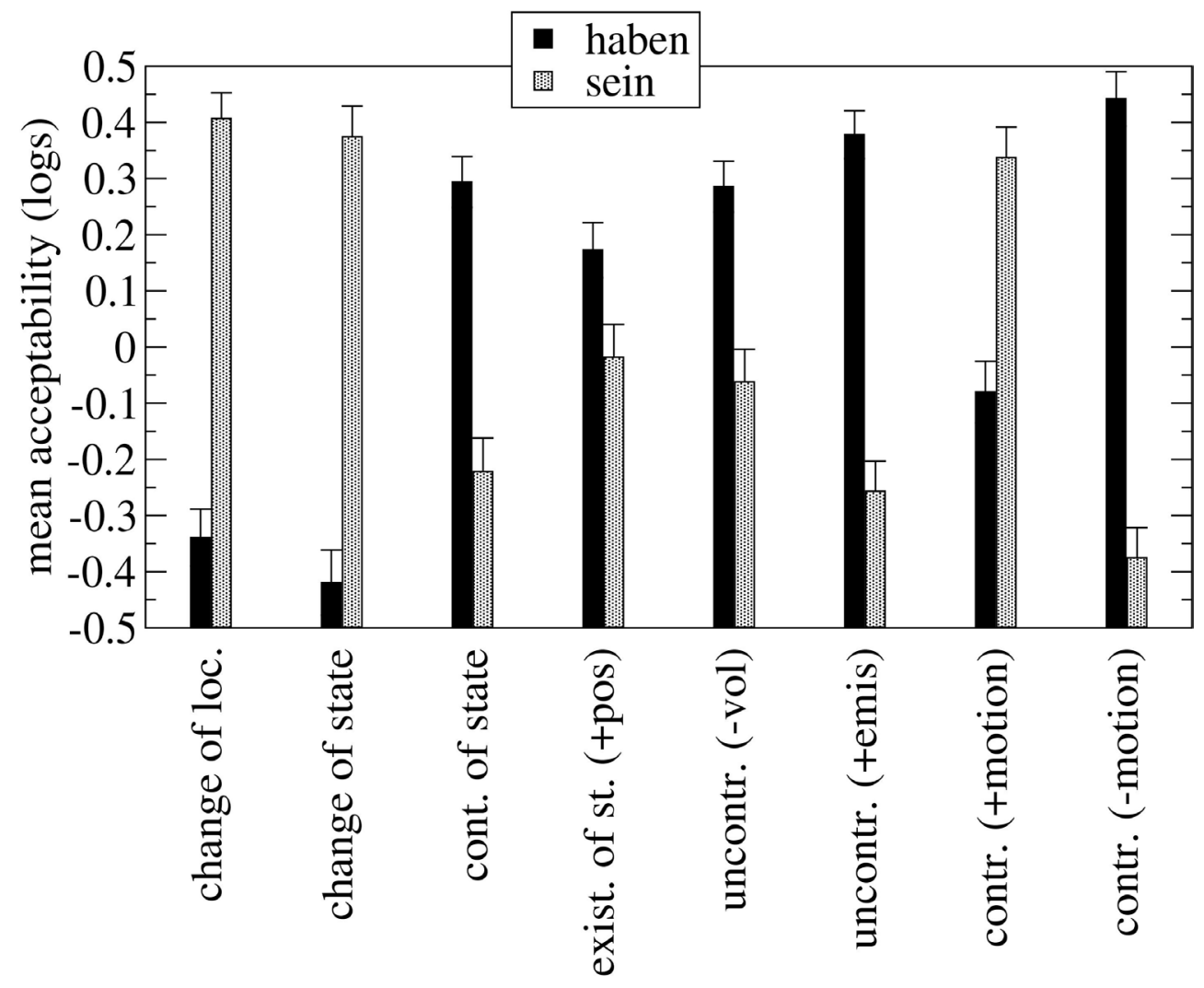

Figure 1

Judgments for auxiliary selection in Experiment 1 by verb class. The figure displays means of normalized, log-transformed judgments. 


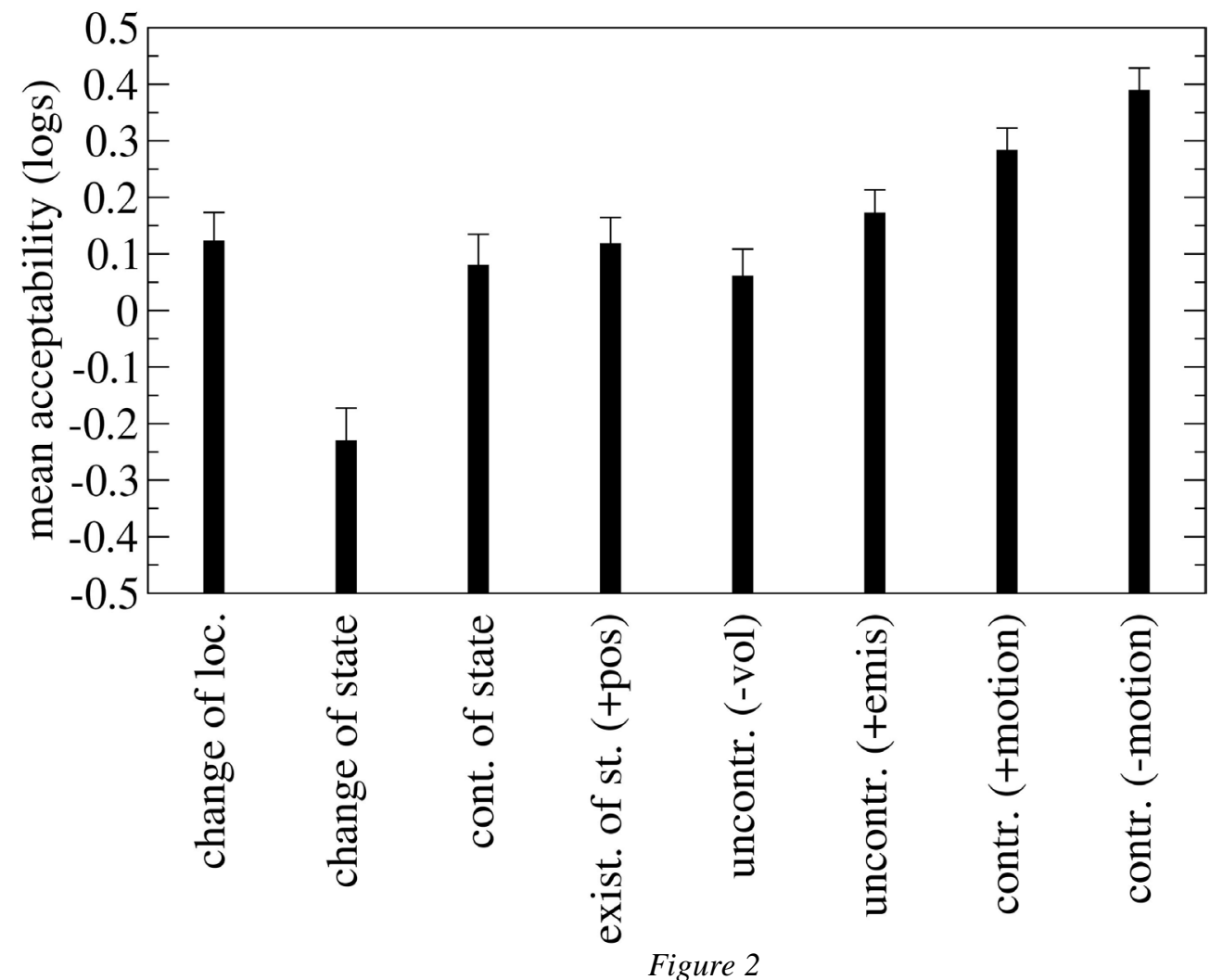

Judgments for impersonal passives in Experiment 1 by verb class. The figure displays means of normalized, log-transformed judgments. 


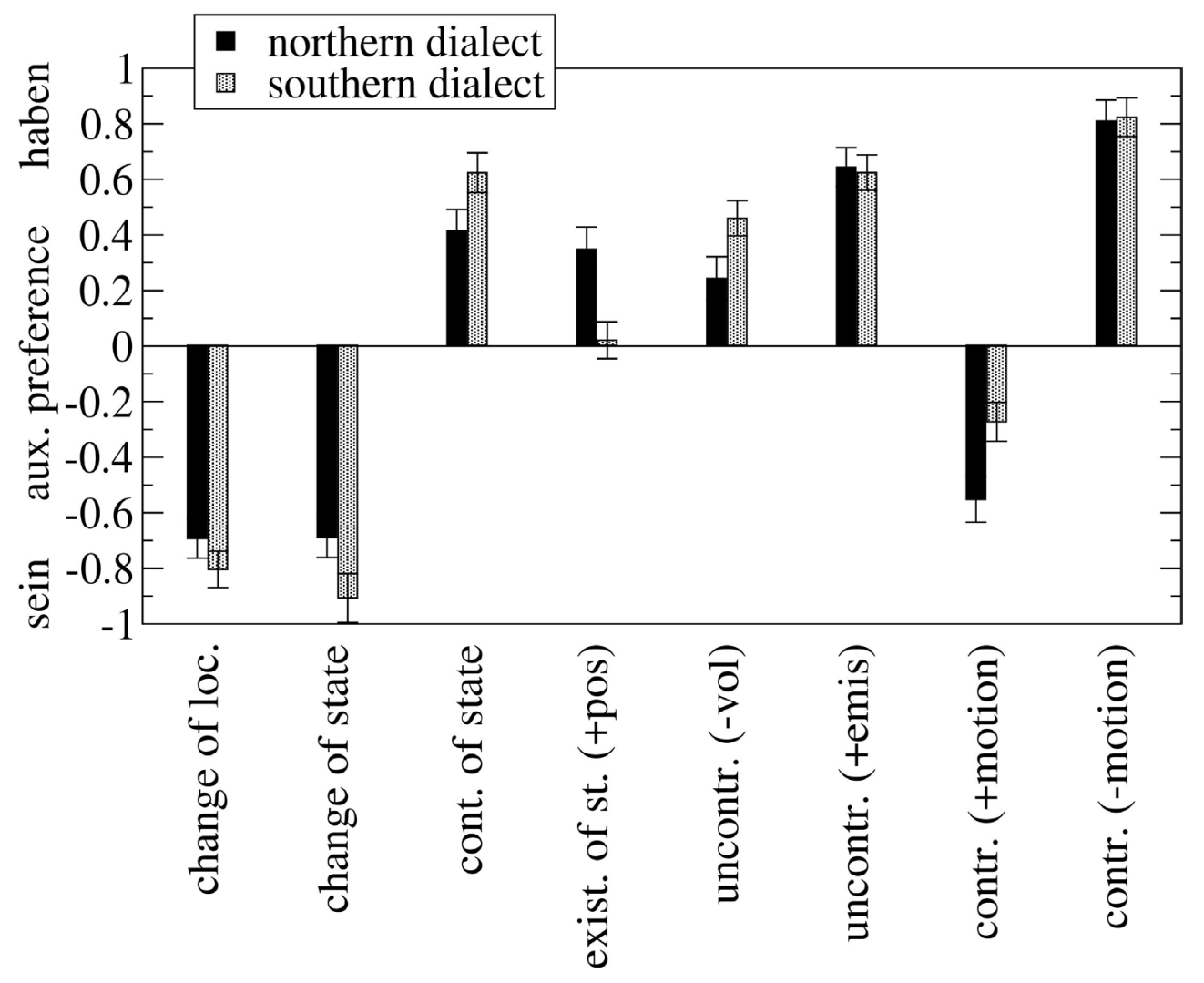

Figure 3

Dialect effects on auxiliary selection in Experiment 1 by verb class. The figure displays auxiliary preferences (mean judgment for haben minus mean judgment for sein). 


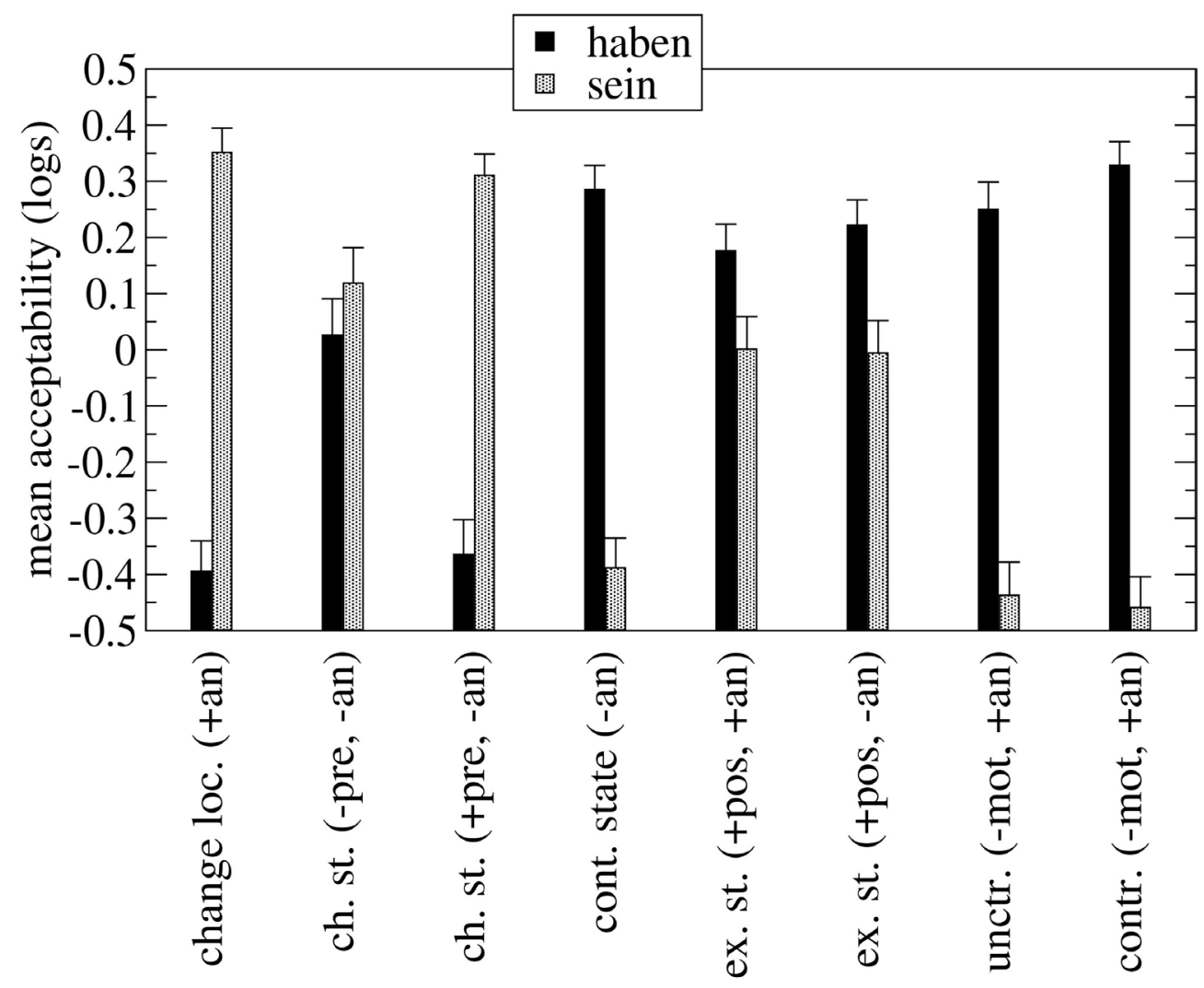

Figure 4

Judgments for auxiliary selection in Experiment 2 by verb class. The figure displays means of normalized, log-transformed judgments. 


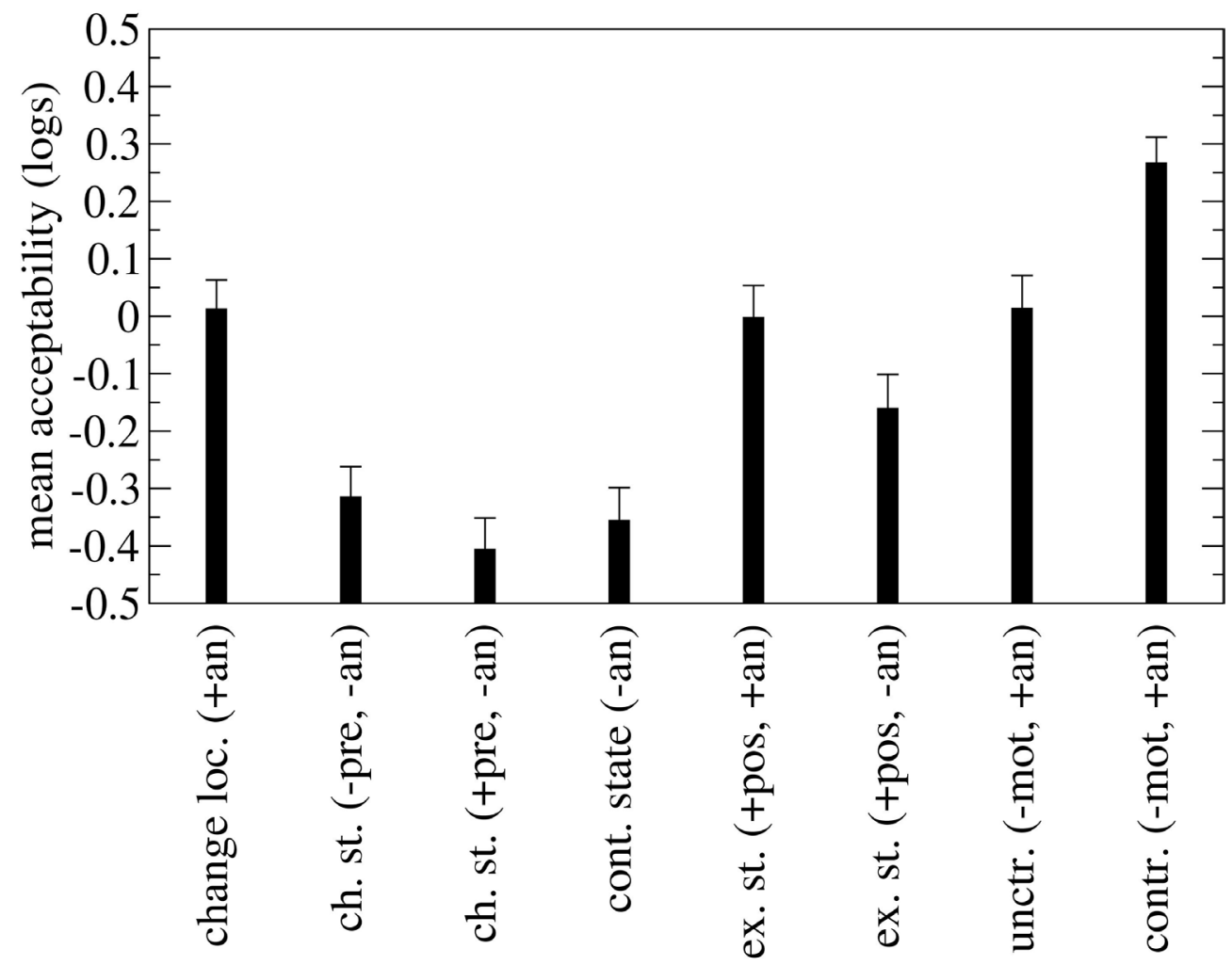

Figure 5

Judgments for impersonal passives in Experiment 2 by verb class. The figure displays means of normalized, log-transformed judgments. 


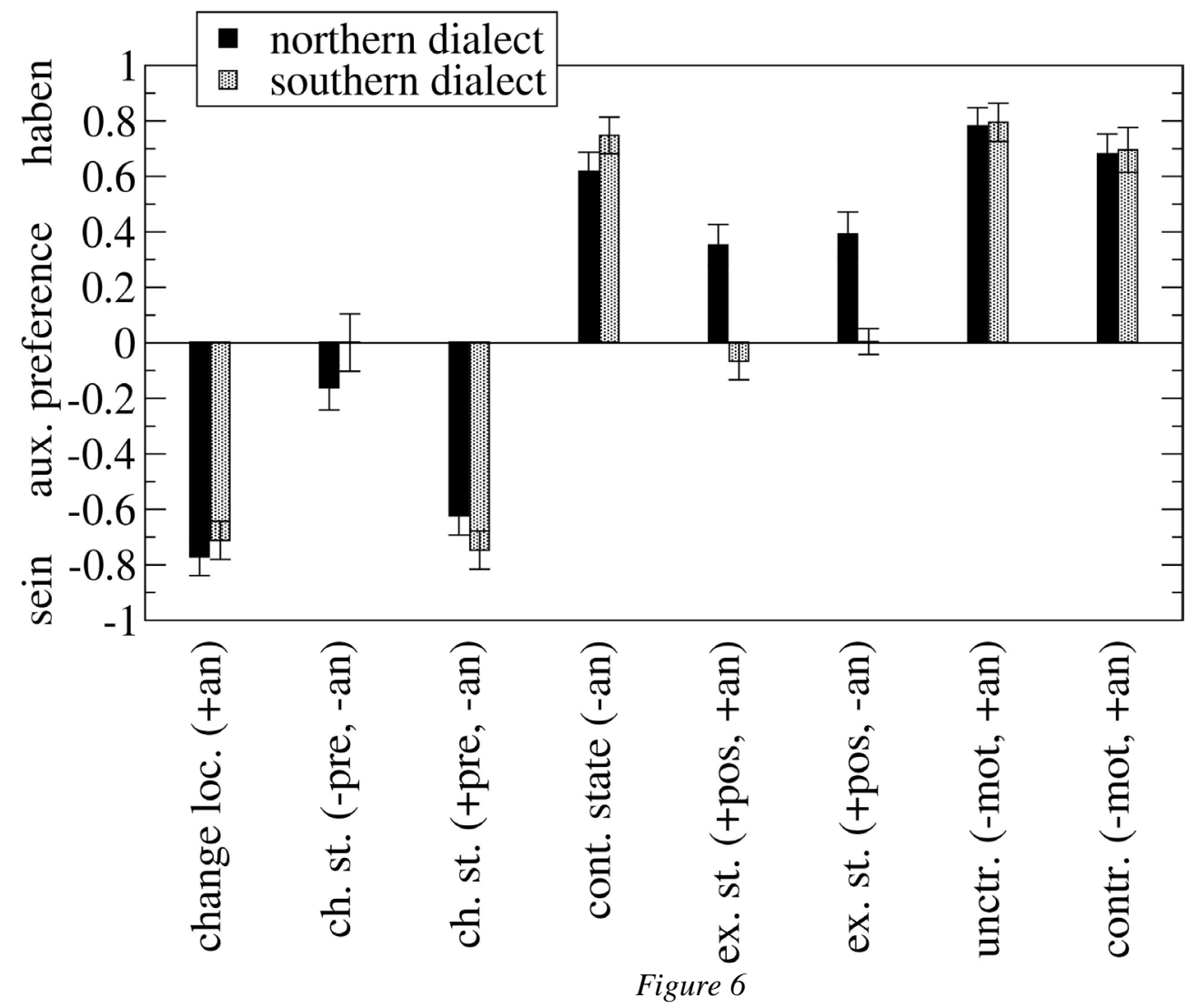

Dialect effects on auxiliary selection in Experiment 2 by verb class. The figure displays auxiliary preferences (mean judgment for haben minus mean judgment for sein). 


\section{FOOTNOTES}

${ }^{1}$ The authors would like to thank Ash Asudeh, Maria Lapata, Géraldine Legendre, Janet Randall, Mark Steedman, and Angeliek van Hout for comments and discussions regarding this paper. We have also benefited from presenting some of this material at the University of Manchester and at MIT. We would like to acknowledge the feedback of three anonymous reviewers for Journal of Linguistics, which has significantly improved this paper. All remaining errors are, of course, our own.

${ }^{2}$ Burzio (1986) is probably the theory that comes closest to a motivating account of why BE is selected by unaccusatives and HAVE by unergatives: the notion of binding between two arguments is at the root of BE-selection for unaccusative, passive, impersonal, and reflexive constructions. There is no explanation, however, of why it is BE and not HAVE that appears in all these constructions.

${ }^{3}$ Levin \& Rappaport Hovav (1995) argue against the role of telicity as a determinant of unaccusativity, and maintain that the crucial notion is the broader one of 'directed change'. The distinction between telic change and directed change, however, appears to be necessary to explain variation in auxiliary selection (see Sorace 2000 for discussion).

${ }^{4}$ Both McClure (1995) and Rappaport Hovav \& Levin (1998) analyze the relative 'elasticity of meaning' of verbs as dependent on the degree of specification of their event structure, which makes them more or less compatible with multiple interpretations. In McClure's analysis, states are the 'building blocks' for all types of aspectual representations and are therefore maximally unspecified. Similarly, Rappaport Hovav \& Levin argue that the event structure template of stative verbs can be 'augmented' to derive more complex templates, for example achievements.

${ }^{5}$ A reviewer argues that unaccusativity cannot be gradient, and we agree: what is gradient are the lexicalaspectual representations of individual verbs, which make them compatible with unergative or unaccusativity syntax, or with both.

${ }^{6}$ According to Grewendorf, the existence of the unaccusative-unergative distinction in German has important ramifications for the analysis of German as a semi pro-drop language, in which nominative case can be assigned to the direct object position.

${ }^{7}$ In Grewendorf's analysis (1989: 23), only an object and a past participle can be placed together in the 'prefield', but not a nominative subject and a past participle. This type of topicalization is normally acceptable with unaccusative verbs but not with unergative verbs because of the different configurational status of their single argument.

${ }^{8}$ A well-known analysis of reflexives in Romance regards the reflexive clitic as a marker of a lexical operation which 'absorbs' the external argument, binding it to the internal argument (for discussion, see Grimshaw 1990, Alsina 1996). Under this analysis, reflexive verbs are unaccusative and categorically require auxiliary BE in standard Italian (see Burzio (1986) on reflexive unaccusatives being the core case for essere selection). However, reflexive unaccusatives exhibit variation in auxiliary selection in many Italo-Romance varieties (see Kayne 1993). In German and Dutch reflexive verbs select HAVE, possibly as a consequence of the fact that these languages do not have cliticization (Haider \& Rindler-Schjerve 1987). 
${ }^{9}$ Impersonal passivization seems to be possible with unaccusatives in some languages, e.g., Turkish (Lewis 1967).

${ }^{10}$ We therefore agree with Levin \& Rappaport Hovav (1995: 141) when they say that 'we take impersonal passivization to be an unaccusative diagnostic - but we take its sensitivity to protagonist control to be an indication that it is a necessary but not a sufficient condition that a verb be unergative for it to permit impersonal passivization.'

${ }^{11}$ The hierarchy represents different degrees of telicity, ranging from inherent change of location (i.e., displacement in space from point A to point B), to change of state (i.e., completed change from state A to state B), to directional change (i.e., gradual change of state with no necessary endpoint) to continuation of state (i.e., absence of change from a give state), to state (i.e., absence of change). See Sorace (2000) for details.

${ }^{12}$ In Borer's view, passivization does not arise from a change in the projection information associated with particular DPs (such as the 'demotion' of the external argument and the 'promotion' of the internal argument), since lexical entries not contain such information. Rather, it results from a structural reversal of the relationship between functional projections in the clause, achieved through the mediation of the passive morpheme, which is an 'event-type shifter': this morpheme is projected as an eventive aspectual projection, whose specifier is filled by one of the arguments of the verb which in turns receives an interpretation as 'subject of result'; the other argument remains in the VP, where it is licensed by a preposition or it is interpreted as an indefinite pro. For intransitive verbs, this operation involves the stranding of the sole argument and no licensed eventive aspectual projection, which results in impersonal passives having an atelic interpretation. However, since the passive morpheme does not project as the head of such an eventive interpretation (unlike passivization of transitive predicates), it must be possible for it to occupy the head of a different functional projection, which Borer suggests might be that determining a process interpretation. While many details of this account are still missing, it seems to be consistent with the observation that 'unaccusative' verbs may allow impersonal passivization if the subject is agentive and shift to an atelic interpretation. The sentence Es wurde von dem Schauspieler im richtigen Moment gefallen 'There was falling by the actor at the right moment' suggests an atelic sequence of repeated acts of falling, rather than a single telic event of falling.

${ }^{13}$ Such inconsistent syntactic behavior has been found for French by Sorace (1995): only core verbs show consistency of syntactic behavior across different diagnostics.

${ }^{14}$ In the experiments reported in this paper, subjects were excluded based on response times and response ranges. Please see the appendix for details on how the response times were recorded.

${ }^{15}$ The high number of lexicalizations (eight per verb class) was necessary to ensure that a meaningful byitem analysis could be conducted. Of course this also requires a high number of subjects to ensure that sufficiently many judgments are obtained for each lexicalization (each test set was seen by seven subjects on average).

${ }^{16}$ A reviewer is doubtful about the goals of Experiment 2 and its significance with respect to the ASH, stating that 'the exercise is trivial in the sense that the construction of the ASH into seven classes is 
sensitive to telicity and agentivity so varying these two factors is undoubtedly going to give effects.' But Experiment 2 was conducted precisely because Experiment 1 did not systematically probe the effects of these factors on non-core verbs in German. The fact that effects were found in other languages does not imply that they would be necessarily found in German, but it is important to test them in order to conclude that an intermediate verb class on the ASH does not display variable auxiliary selection behaviour in this language.

${ }^{17}$ According to Levin (1993: 261), totter is a verb of body-internal motion which, in isolation, does not entail displacement, but in the presence of a directional phrase allows a reading in which it does. 